\title{
Bir Bunalım Çağında Dirliği İnşa Etme Çabaları ve Yunus Emre
}

\author{
iD Celalettin \\ VATANDAŞ * \\ iD Saniye \\ VATANDAŞ**
}

* Prof. Dr., Süleyman Demirel
Üniversitesi, İletişim Fakültesi,
Gazetecilik Bölümü
cvatandas@yahoo.com
Orcid ID: 0000-0003-1431-3553
** Doç. Dr., Isparta Uygulamalı
Bilimler Üniversitesi, Teknik
Bilimler MYO.,
saniyevatandas@isparta.edu.tr
Orcid ID: 00000-0002-3646-9332

Gönderilme/ Received

27.09.2021

Kabul Tarihi/ Accepted

15.10.2021

Yayın Tarihi/Published

17.11.2021

\section{Öz}

Özellikle 13. yüzyıl Anadolu tarihi için oldukça önemli bir dönemdir. Çünkü bu yüzyılda Anadolu tam anlamıyla bir bunalım devrine sahip olmuştur. Anadolu Selçuklu Devleti'nin çöküşünü takiben Moğolların Anadolu'yu istila etmeleriyle siyasi, askeri, ekonomik, dini düzen bozulmuştur. Farklı inançlara mensup toplulukların Anadolu'ya gelmeleri ise mevcut kaosu daha da yaygınlaştırmış ve derinleştirmiştir. Anadolu'daki inanç ve düşünce önderleri arasında yer alan Yunus Emre, yaşanmakta olan mevcut bunalımı sonlandırmanın yollarını aramıştır. Bu konuda diğer birçok inanç ve düşünce önderi de benzer arayışın içindedirler. Yunus Emre bozulan birlik ve beraberliği yeniden inşa edebilmek için "dirlik" kavramını önemsemiş ve "dirlik" üzerinde durmuştur. Dirliği inşa edebilmek için kişilere yönelmiş onların duygu ve düşüncelerini düzenlemenin çabasını yürütmüştür.

Anahtar Kelimeler: Yunus Emre, Anadolu, Dirlik, Moğol istilası

Kaynak gösterme / To cite this article: Vatandaş, C., \& Vatandaş, S. (2021). Bir Bunalım Çağında Dirliği İnşa Etme Çabaları ve Yunus Emre. The Journal of Communication and Social Studies, 1(1), 1-29. 


\title{
Efforts to Build Peace and Confidence in an Age of Decrease and Yunus Emre
}

\author{
Celalettin \\ VATANDAŞ *
}

Saniye

VATANDAŞ***

* Prof. Dr., Süleyman Demirel
University, Facult of
Communication, Journalism
cvatandas@yahoo.com
Orcid ID: 0000-0003-1431-3553
** Assoc. Prof. Dr., Isparta
University of Applied Sciences,
Technical Sciences Vocational
School
saniyevatandas@isparta.edu.tr
Orcid ID: 00000-0002-3646-9332

Gönderilme/ Received 27.09.2021

Kabul Tarihi/ Accepted 15.10.2021

Yayın Tarihi/Published 17.11.2021

\begin{abstract}
Especially the 13th century is a very important period for Anatolian history. Because in this century, Anatolia had a period of depression in its full sense. Following the collapse of the Anatolian Seljuk State, the political, military, economic and religious order was disrupted by the Mongols' invasion of Anatolia. The arrival of communities of different faiths to Anatolia further spread and deepened the existing chaos. Yunus Emre, who is among the leaders of belief and thought in Anatolia, sought ways to end the current depression. In this regard, many other belief and thought leaders are in a similar search. Yunus Emre gave importance to the concept of peace and confidence (dirlik) and focused on peace and confidence (dirlik) in order to rebuild the unity and solidarity that was broken. In order to build dirlik, he directed towards people and made an effort to organize their feelings and thoughts.

Keywords: Yunus Emre, Anatolia, Dirlik, Mongolian invasion
\end{abstract}




\section{Giriş}

13. ve 14. yüzyıl genel manada Müslümanların tarihi özel olarak da Anadolu tarihi açısından oldukça önemli bir zaman kesitini oluşturmaktadır. Zira bu dönem Anadolu'nun Moğollar tarafından işgal edildiği, Anadolu'da siyasi, askeri, dini, ekonomik, kültürel bir iradenin olmadığı, mevcut iradenin de Moğollar adına hareket ettiği bir çağdır. Anadolu Selçuklu devletinin iktidar mücadelelerine kurban gitmesi, Moğolların işini kolaylaştırmıştır. Moğollar nedeniyle Anadolu'ya doluşan farklı inanç ve karakterdeki topluluklar ise Anadolu'nun bir bunalım çağı yaşamasına katkı sağlamışlardır. İnsanların can ve mal güvencesini kaybettikleri, din ve inanç birlikteliğinin kaybolduğu, siyasi, askeri ve ekonomik istikrarın kaybolduğu bu dönemde bazıları mevcut "bunalımdan" kurtuluşun yol ve yöntemini bulmanın, bulduklarını da insanlara sunmanın çabası içerisinde olmuşlardır. Bazılarına göre söz konusu bunalımdan kurtuluşun tek yolu, işgalci Moğollara fiilen başkaldırıdan geçmektedir; Ahi Evran ve liderliğini yaptığı Ahîler bu görüştedirler. Diğer bazılarına göre ise Moğollarla uyumlu yaşamak, hatta Moğollarla işbirliği halinde olup dostluk ilişkileri geliştirmek söz konusu bunalımın sona ermesine katkı sağlayacak bir yöntemdir. Kalenderîler bu görüştedirler. Diğer bazıları ise işgalci Moğollarla hiçbir şekilde muhatap olmadan "yeni insan" tipini oluşturmanın zor ve uzun yolunda yolculuk yapmak gerektiği düşüncesindedirler. Bunlara göre tek tek şahısları eğitip hakikati bilen ve hakikate göre yaşayan bir toplum inşa etmek tüm bunalımı sona erdirecek bir yöntemdir. Hacı Bektaş Velî ve Yunus Emre bu görüştedirler. Bu görüşlerine uygun olarak da tüm hayatları boyunca kişilere seslenmişler, onları hakikatin ışığından nasiptar yapmaya çalışmışlardır. Bunu yaparken belirli değerleri ön plana çıkarmışlardır. Yunus Emre için söz konusu değerlerden birisi “dirlik”tir. "Dirlik"i inşa etmenin çabası içerisinde şiirler söylemiş, insanların gönüllerine dokunarak hakikatin ışığını yakmaya çalışmıştır.

\section{Anadolu'da Bir Bunalım Devri: 13-14. Yüzyıllar}

13. yüzyıl Anadolu'su, Anadolu Selçuklu Devleti’nin en güçlü devrine de tarihten silinişine de tanık olunan bir coğrafyayı temsil etmektedir. 1220-1237 yılları arasında hüküm süren Alaeddin Keykubad döneminde her bakımdan en güçlü ve parlak yıllarını yaşayan Anadolu Selçuklu Devleti, takip eden dönemde hızla güç kaybına uğradı. Anadolu'daki dirlik ve düzen hızla bozulmaya başladı. Alaeddin Keykubat'ın çocuk yaştaki haleflerinin arasındaki taht kavgaları, dönemin önde gelen isimlerinin veya belirli zümrelerin de sürece müdahil olmalarıyla şiddetlenip, ülkede dirlik bırakmadı. Çocuk yaştaki haleflerin ileri gelen devlet adamlarının veya zümrelerin desteğini alma ihtiyacı, yönetim merkezi Konya'dan başlayıp halka halka genişleyerek tüm Anadolu'yu kuşatan bir kargaşa ve kaosun Anadolu'da egemen olmasına yol açtı. Saltanat mücadeleleri önce siyasi ve askeri iradeyi tahrip etti; takiben ekonomik, dini, kültürel çöküş baş gösterdi. Bu sırada doğudan batıya doğru ilerleyen Moğol istilası tüm mevcut olumsuzlukların üzerine son kalmış dirlik ve düzen kırıntılarını da yok etti. Anadolu paganist ve cani Moğollar tarafindan istila edildi. Moğolların paganizmi, Moğolların önünden kaçarak Anadolu'ya gelen tüm paganist inanç mensuplarını, canilikleri ise kural ve kaide tanımayan ve tanımak da istemeyen tüm başıbozuk toplulukları Anadolu'da pervasızca hareket eder 
hale getirdi. Anadolu, içten ve dıştan her türlü taciz edilen bir coğrafyaya dönüştü.

Moğolların Anadolu topraklarına ilk tecavüzleri İbn Bîbî’nin bildirdiğine göre 1231 tarihinde gerçekleşti (İbn Bibi, 1996, s. 420-421). Ancak asıl istila 1240’tan sonra gerçekleşti. Moğol istilası öncesinde patlak veren isyanlar, iktidar mücadeleleri ve savaşlar Moğol istilası için uygun bir ortam hazırladı. Isyanlar içerisinde 1240 yılında patlak veren Babaî isyanı çöküş sürecinin önemli eşiklerden birisiydi. Her geçen gün güç kaybeden Selçuklu tarafindan zorla bastırılan bu isyan Anadolu'nun siyasi, askeri gücünü ileri düzeyde zayıflatıp, Moğol istilasına tamamen hazır hale getirdi. Daha da önemlisi dini görünümlü fakat esasen daha çok siyasi ve ekonomik amaçları içeren bu isyan Anadolu'yu dini açıdan da derin bir karmaşaya mahkûm etti. Böyle olunca Selçuklunun 1243 yılında Kösedağ'daki yenilgisi kaçınılmaz oldu. Kösedağ yenilgisi Anadolu'daki Selçuklu otoritesinin sonunu getirirken, Moğolların Anadolu'da egemen irade haline gelmelerini sağladı. Moğollar ise istilalarını kolaylaştıran tüm karmaşa, ayrılık ve çatışmaları destekleyerek Anadolu'ya egemen olan bunalımı çok yönlü ve daha da derinlikli bir hale getirdiler.

Esasen Anadolu tüm tarihi boyunca arada bir yaşanan sükûnet dönemleri hariç hep büyük devletlerin, dinlerin, toplumların karşılaştığı ve çatıştığı bir coğrafya olmuştur. 13. yüzyıl öncesi birkaç yüzyıllık dönem ise bunun dışında değildi. Yoğun göçler farklı din ve kültürlerin bir arada yaşamasını zorunlu kılmış, tüm Anadolu'da egemen olan bir siyasi ve askeri iradenin olmaması, olanların da kısa süreli ve daha çok bölgesel olması, Anadolu coğrafyasını karmaşanın ve çok yönlü faktörlerin beslediği bunalımların coğrafyası kılmıştır. Özellikle 12-14. yüzyıllarda arada bir yaşanan sükûn dönemleri, bu coğrafyada küçük huzur adacıkları olmanın ötesine geçmemiştir.

13. yüzyılın Anadolu'su ekonomik açıdan zor zamanlara tanık olunan bir çă ve coğrafya olmuştur. Her geçen gün artan açlık ve sefalet Anadolu'nun değişmeyen özelliği haline gelmiştir. Siyasi, askeri, dini, kültürel alanlarda olduğu gibi ekonomik alanda da Moğolların işgali ekonomik hayatı hepten felç etmiştir. Moğollara karşı başlayan çarpışmalar nedeniyle tarlaların ekilememesi veya ekinlerin göçebeler yahut birbiriyle çatışan topluluklar tarafından hasara uğratılması Anadolu'nun ekonomik açıdan iflas etmesine, tarıma ve hayvancılığa dayanan ekonomik düzenin bozulmasına yol açmıştır. Moğolların önünde kaçarak Anadolu'ya doluşan başıbozuk topluluklar yerleşik köylüleri taciz etmişler, ekonominin belkemiğini oluşturan bu kesimlerin topraklarını terk etmek zorunda kalmalarına yol açmıştır (Cahen, 2000, s. 313). 1250'lere gelindiğinde Anadolu topraklarındaki ekonomik bunalımın had safhaya eriştiği görülmektedir. Üç kardeşin birden tahta oturması askeri yapıdan ve siyasetten başlayan ekonomiye, kültüre ve dine uzanan düzensizliği zirveye ulaştırmıştır. Saltanat merkezindekilerin kendi çıkar ve keyiflerini düşünmelerinin yol açtığı sorumsuzluklar ve keyfi harcamalar, Karakurum'daki Büyük Moğol kaanlarının cüluslarında veya bir problem dolayısıyla gönderilen elçilerin beraberlerinde götürdükleri yüklü hediyeler süregelmekte olan ekonomik krizi derinleştiren sebepler arasında önemli bir yer işgal etmiştir. Bu kötü ekonomik tablo karşısında iradesiz Selçuklu idarecileri Moğol yöneticilerin huzuruna çıkıp merhamet dilenerek kendilerini küçük duruma düşürürlerken aslında 
Anadolu'daki insanların ikballerini kararttıklarının farkında olamadılar. 1256'da gerçekleşen Sultanönü savaşında Selçukluyu bir kez daha yenen Moğollar, Anadolu'ya yerleşmeye başladılar. Selçuklu ise Moğol'a yıllık ödedikleri haraca ilaveten kalıcı hale gelen Moğol ordusunun masraflarını da üstlenmek zorunda kaldı (Erdem, 2003, s. 51). Moğolların Anadolu'daki ekonomik yıkıma katkılarını anlamak için Selçuklu devletinden tahsil ettikleri vergi miktarı dikkate dikkat çekicidir. Baycu Noyan'ın (1241-1246) Anadolu Selçuklularına koyduğu 360.000 dirhem vergi, Hülagu Han döneminde (1256-1265) 1.200.000 dirheme ve ilaveten 500 parça Antalya kemha (bir tür ipek) kumaşına, 3.000 parça dibac (bir tür ipek) kumaşına, 500 at, 500 deve ve 5.000 küçükbaş hayvana çıkmıştır (Togan, 1981, s. 303). Ancak Moğol/İlhanlı idaresi tarafından devamlı düzenlemeler yapılmasına rağmen Anadolu'dan istenilen meblağ bir türlü toplanamamıştır. Çünkü Anadolu'daki insanların ekonomik takatleri kesilmiş durumdadır. Öte yandan devletin sürekli artan masraflarına, ordunun ihtiyacına hanedan azalarının aşırı israfi da eklenince bunları karşılamak için konan ilave vergiler insanları dayanılmaz bir açlığa ve derin bir sefalete mahkûm etmiştir.

Moğol istilası öncesinde Selçuklu devleti belirli düzeyde de olsa Anadolu'da otorite tesis etmiş, can ve mal güvenliğini belirli düzeyde sağlamış durumdaydı. Ekonomi, din, kültür, sanat alanlarında da olumlu bir ortam tesis edilmişti. Selçuklu yöneticileri Türk, Fars, Arap coğrafyasından gelen âlimleri, önemsiyor, onlara itibar ediyor ve yanlarında tutmanın çabasını yürütüyorlardı. Bu çabalar sonucunda İran'dan ve Arap ülkelerinden gelen önemli kişiler, başta başkent Konya olmak üzere Kayseri, Kırşehir, Tokat, Sivas gibi şehirlere yerleşmiş durumdaydılar (Ocak, 2006, s. 429; Kartal, 2006, s. 493). Özellikle Konya, Kayseri ve Sivas gibi büyük şehirlerde bulunan medreselerde eğitim faaliyetleri yoğun bir şekilde devam ediyordu. Kültürel hayat canlı, ekonomik faaliyetleri iyi durumdaydı. Ancak Alaeddin Keykubat'in vefatını takiben başlayan taht merkezli yeni süreç ve takiben Moğol istilası ile tüm düzen temelden tahrip oldu. Anadolu'daki düzenin bozulmasına ilaveten Moğollar nedeniyle topraklarını terk eden kitleler düzensiz bir şekilde Anadolu'da doluşmaya başladılar. İran, Irak ve Türkistan'dan kaçan ve görece farklı inanç ve anlayışlara mensup çok sayıda topluluk Anadolu'da başıbozuk bir şekilde dolaşır hale geldi. Bunların bir kısmı genel çerçevesiyle İslami çizide yer almasına karşılık önemli bir kısmı Şamanizm, Manizm, Zerdüştlük, Budizm gibi dinlerin etkisinde olan topluluklardı. Dönem Anadolu halkının göçebe olan kesimi ekseriyetle İslam kisvesi altında birçok eski Şamanist yaşayış biçimi ve inancı olanca biçimiyle devam ettiriyordu. Göçebe ve yarı göçebe topluluklar, eski isimleri 'kam' olan şimdilerde 'baba'ya dönüşmüş Türkmen dervişlerin etkisi altında eski geleneksel inançlarına sıkı sıkıya bağlı durumdaydılar. $\mathrm{Bu}$ nedenle ölülerini hâlâ silahları ile göçmen Türk topluluklarına rastlanması hiç şaşırtıcı değildir. Hatta 13. asırda Selçuklu sultan ve vezirlerinin bile öldüklerinde bedenlerinin mumyalanmaları dikkat çekicidir (Turan, 1998, s. 356).

Selçuklu dönemi ve öncesinde Anadolu'ya gelen Türk topluluklarının büyük çoğunluğu bir süre Müslümanların çoğunlukta olduğu topraklarda iskân ettikten, İslam'ı öğrendikten sonra Anadolu'ya gelmişlerdi. Fakat Moğolların önünde Anadolu'ya doluşan topluluklar için aynı şeyi söylemek mümkün değildir. Manizm, Zerdüştük, Budizm gibi dinlerin özellikle de Şamanizm birçok inanç ve 
ritüeli bu topluluklar üzerinden Anadolu'ya taşınmıştır. Ateş ve Ocak kültü bunun en somut örneklerinden birisidir (Akkuş, 2013, s. 20). Dönemin önemli araştırmacılarından Osman Turan'ın ifadesiyle söylemek gerekirse; Moğolların önünde batıya yönelen topluluklar Müslüman ve Şamanî olmak üzere iki kol halinde Anadolu'ya doluşmuş, özellikle de uç bölgelerine yığılmışlardı (Turan, 2012, s. 45). Bu durum Anadolu'daki toplulukların Moğol saldırılarından kaynaklanan fiili dağınıklığın inanç ve anlayışları da kapsayacak kadar kapsamlı ve derinlikli hale gelmesine yol açmıştır. Böylelikle Anadolu benzeri az görülür bir inanç karmaşasına tanık olmaya başlanmıştır. Farklı tasavvuf ekolleri Anadolu'da güç haline gelmenin çabasını yürütmeye başlamıştır.

$\mathrm{Bu}$ aşamada kısaca da olsa tasavvufa değinmek gerekiyor. Tasavvuf anlayışının İslam dünyasındaki geçmişi İslam'ın 2. asrına kadar uzanmaktadır. Tasavvuf anlayışı bazı bakımlardan kişilere güven duygusu vermek; mevcut siyasi, askeri karışıklıklar karşısında bir güven ortamı inşa etmek gibi fonksiyonlar üstlenmişse de aynı kavramsal çatının altında bozucu, dağıtıcı, tahrip edici anlayış ve yaşama biçimleri de kendisine yer bulabilmiştir. Mevcut toplumsal, askeri, ekonomik, siyasi şartlar gereği Müslüman olma ihtiyacı hisseden ancak gerçekte mensubu göründüğ̈ yeni inancı içten gelerek kabullenmeyenler İslam dışı inanç ve yaşantılarını devam ettirebilmenin önemli bir imkânı olarak tasavvufu kullanmışlardır. Bazı şahsiyetler çevrelerine topladıkları kitlelerle önemli güç merkezi haline gelmenin çabasını yürütürlerken tasavvuf anlayış ve örgütlenme biçiminden yararlanmışlardır. Tasavvufun akışkan karakteri bu gibi kişiler ve kesimler için gizli amaçlarını veya kişisel planlarını yürütmenin imkânını sağlamıştır. Böylelikle Anadolu, tasavvuf adı altında her türlü inanç ve anlayışın, kabul ve hayat tarzının boy gösterdiği bir coğrafya haline dönüşmüştür.

\subsection{Yüzyıl Anadolu'sunda İnanç Ekol ve Grupları}

Moğol istilasından önce veya sonra Anadolu'ya gelenler arasında belirli bir ekolü temsil eden anlayış ve inançların lider düzeyinde temsilcileri vardı. Bunlar, hemen hiç zorlanmadan, ne yapacağını bilemeyen, çoğu başıbozuk bir halde Anadolu coğrafyasında gezinip duran topluluklar tarafindan kabul görerek önemli bir güç haline gelmeyi başardılar. Bunların bir kısmı İran, Mısır, Irak ve Suriye'den diğer bir kısmı ise Horasan, Maveraünnehir ve hatta Türkistan'dan gelen derviş ve sûfilerdi. Bu durum Anadolu'yu Irakîler ve Horasanîler olarak ifade edilebilecek iki büyük tasavvuf ekolünün temsil ettiği ve bu anlayışlara dayanan tarikatların buluştuğu bir bölge haline getirdi. Zühd ve takva anlayışının ağır bastığı ahlakçı bir ekol olan Kadirî, Rufaî ve Sühreverdî tarikatları birinci kesime dâhildir. İkincisi kesim ise, Horasan'ın yanı sıra Maveraünnehir ve Hârizm bölgelerinden gelenleri de kapsayan, melâmet prensibini benimsemiş, inanç ilkeleri konusundan oldukça esnek karakterli, aşk ve cezbeye önem veren, kitabi ilke ve ölçülere itibar etmeyen kesimlerdi. Bu ikinci kesimde yer alan dervişlerin birçoğu garip kıyafetleri ve meczupvari yaşayışlarıyla eski "kamlar"ın hatırasını İslamî bir şekil altında yaşatan Türkmen babalarıydı. Bunların sözde kerametleri cahil halk arasında dilden dile dolaşıyor bu da itibar ve güçlerini pekiştiriyordu. Bunlar, Türk topluluklarının eski gelenekleriyle uyumlu olmak üzere, İslam'ı basit şekli ölçüler içinde bir takım mistik özelliklerle donanmış bir hale dönüştürerek Anadolu'ya yerleşme 
çabası içerisindeki Türk topluluklarına telkin ediyorlardı (Köprülü, 1922, s. 50-51).

Moğollar Anadolu'yu istila ettiklerinde, Anadolu sosyal ve dini gruplaşmalar açısından oldukça zengin bir görünüm arz etmekteydi. Oldukça farklı tasavvuf ekollerine mensup şahsiyetler doğudan ve kuzeydoğudan Anadolu'ya gelmiş durumdaydılar. Yesevî, Kalenderî, Cavlâkî, Haydârî, Mevlevi, Babaî, Bektaşî, Şemsî, Evhadî, Rufaî, Ahî, Ekberî, Kübrevî ismi altında faaliyet yürüten dervişler 13 yüzyıl ve 14. yüzyıl Anadolu'sunun genel dini görünümünün parçalarını teşkil ediyorlardı. Bunların bazıları birbirlerinden tamamen ayrı ve farklı değildi. Aralarında önemli benzerlik taşıyanlar vardı. Örneğin Cavlâkîler Kalenderîlerin içinden çıkmaydı. Yine bazıları diğer bazıları için öncü konumundaydı. 13. yüzyılı esas alarak ifade etmek gerekirse, dönemin Anadolu'sunda Türkmen toplulukları arasında yer edinmiş ve sonraki anlayış ve yaşayış ekollerine de kaynaklık yapan bazı önemli inanç ve yaşayış ekolleri şunlardır:

\subsection{Yesevîlik}

Yesevîlik, Nakşibendî geleneğinde önemli yere sahip Şeyh Yusuf Hemedânî (ö. 1140) tarafından yetiştirilen ve "Pîr-i Türkistan" ismiyle ünlenen Ahmed Yesevî tarafindan kurulmuştur. Ahmed Yesevî, bugünkü Çin’in Doğu Türkistan bölgesinde yer alan Aksu bölgesindeki Sayram kasabasında doğmuştur. Doğum tarihi kesin olarak bilinmemekle birlikte 11. asrın sonlarına doğru doğduğu ve 70'li yaşlarda vefat ettiği bilinmektedir. Yaygın kabule göre 1166 yılında vefat etmiştir. Ahmet Yesevi konusundaki araştırmalarıyla tanınan Devin DeWeese'nin bütün mevcut bilgileri göz önünde tutarak Ahmed Yesevî’nin diğer sûfîlerle bağları hakkında oluşturduğu "en olası senaryo" şöyle özetlenebilir: Ahmed Yesevî memleketi Türkistan'dan Maverünnehr ve Horasan'a belki de Bağdat'a seyahat etmiş, Sühreverdîlerle hatta kendinden biraz genç olan Necmeddîn Kübrâ'yla (ö.1221) irtibat kurmuş, sonra da memleketine dönerek kendi dergâhını inşa etmiştir (Karamustafa, 2017, s. 134).

Ahmed Yesevi, Türklerin İslam'a yeni girdiği, İslam'ı tam kabullenmedikleri gibi İslam öncesi Şamanist, Budist, Manihesit inançları da tam terk etmedikleri, bu nedenle inanç kargaşasının yoğun yaşandığ Yaşadığı zamanın siyasi şartları son derece olumsuz olup, toplumsal kargaşanın egemen olduğu bir dönemdir. Ahmed Yesevi böylesi bir dönemde ve inanç konusunda tam bir karmaşaya sahip topluluklar arasında İslami inanç ve yaşantının temsilciliğini yapmaya ve çevresindeki insanlara bunu anlatmaya çalışmıştır. Temsil ettiği tasavvufi gelenek İslami anlayış ve yaşayış tarzları içerisinde özel bir tarzı temsil etmektedir. İçinde bulunduğu coğrafyanın ve zamanın şartları gereği, İslam anlayışının şekillenmesinde Fars sûfîliğinin (Ocak, 2012, s. 32) izleri oldukça güçlüdür. Budist, Şamanist ve Maniheist kültürün içinden gelen göçebe ve yarı göçebe Türk topluluklara sahip olduğu İslami anlayışı sunmanın çabasını yürütmüştür. Fakat Ahmed Yesevi'nin inanç ve görüşleri mensubu olduğu coğrafya ve toplumla sınırlı kalmamış, Hâkim Ata, Mansur Ata, Said Ata gibi halifeleri aracılığıyla Orta Asya'da geniş bir coğrafyaya yayıldığı gibi, Maveraünnehir ve Fergana vadisinde kök saldıktan sonra Harezm bölgesine, oradan da Fars bölgesine geçerek çok büyük coğrafyadaki topluluklar arasında yaygın bir şekilde kabul görmüştür. 
Fakat Yesevîlik yayıldığı farklı coğrafyalardaki toplulukların yerleşik inançlarından kendini koruyamamış, böylelikle bölgelere göre değişen formlara ve niteliğe sahip olmuştur. Yesevî inanç ve düşünceler Fars bölgesindeki Zave şehri merkez olmak üzere 12. yüzyıl sonlarında Kalenderîlik ile irtibata geçmiş, bu irtibattan Haydarîlik tarikatı doğmuştur. Yesevîlik'in Anadolu istikametinde daha batıya doğru yayılışını Moğol istilâsı hızlandırmıştır. Yesevî dervişleri, hızla gelişen istilanın önünden kaçarak çeşitli gruplar halinde, meslektaşları olan Haydarîler ile birlikte Harezm, Horasan ve Azerbaycan üzerinden Anadolu'ya girdiler. Yesevî inanç ve görüşleri, doğduğu ve geliştiği coğrafyanın şartlarına benzer nitelikteki Anadolu coğrafyasında da yaygın bir şekilde kabul gördü. Yesevîlik Asya'nın İslamlaşmasında önemli rol oynadığı gibi Anadolu'nun bugün sahip olduğu dini görüntünün oluşmaya başladığı 13. yüzyıla da damgasını vurdu ve özellikle göçebe Türk toplulukları arasında etkili oldu. Zira İslam'la henüz yeni tanışmış, İslam öncesi inanç ve geleneklerini aynen denecek düzeyde sürdüren kişilerin/toplulukları sarsmadan İslam'a yönelmesine katkı sağlamıştır. Mevcut pek çok yanlışa itiraz etmeyerek, İslami olan ilke ve ölçüleri de zorlamadan sunarak yumuşak bir geçişe aracılık yapmayı hedeflemesi yaygınlaşmasının en önemli sebebini teşkil etmektedir. Bu özellikleri sebebiyle, Yesevîlik'ten sonra gelen hiçbir tarikat onun nüfuzunu kıramamış; hatta Yesevîliğin nüfuzunu da koruyarak kendi öğretilerini Yesevîlik üzerine bina etmelerine yol açmıştır. Böylelikle çok sayıda farklı tarikat içinde kendine yer bulan Yesevîlik, varlığını bu tarikatlar içinde sürdürmüştür. Örneğin bir taraftan Nakşibendîlik, diğger taraftan Kübrevîlik içinde yaşamaya devem etmiştir (Yılmaz, 2016, s. 61).

\subsection{Haydarîlik}

13. yüzyıl Anadolu'sundaki önemli sûfî hareketlerinden birisi de Haydarîliktir. Kutbeddin Haydar (ö. 1221'den sonra) isimli bir Türkmen sûfîsi tarafindan kurulmuştur. Kutbeddin Haydar, Haydarilik ilke ve inançlarını Zâve'de yaşarken Yesevîlikten ve Kalenderîlikten etkilenerek tespit etmiş, tarikatının temellerini orada kurmuştur. Kısa sürede çevresine önemli bir kitle toplamayı başarmıştır. Temelde Yesevî-Bektaşî geleneğine mensup görünen Kutbeddin Haydar, Köprülü'ye göre, Şî̀-Batınî akidesinin etkisi altında bir şahsiyettir. Ocak'a göre Yesevîlik'in Kalenderî inanç ve anlayışlarıyla birleşmesi Haydarî tarikatını doğurmuştur (Ocak, 2012, s. 37, 38). Haydarîlik, temelde Kalenderîlik tarikatı ile aynı düşünce sistemine bağlıdır. Benimsediği düşünce biçimi, tarikat ayin ve erkânı, dervişlerin dış görünüşü gibi konularda Kalenderîlik'le hemen hemen aynı özellikleri göstermektedir (Köprülü, 1996, s. 50). Haydarîler, ibadet kastıyla saç, sakal, bıyık ve kaşları ustura ile kazımanın ismi olan "çehâr darb" (Çârdarb) uygulamasının diğer gereklerini yapmakla birlikte, bıyıklarını tıraş etmezlerdi. $\mathrm{Bu}$ açıdan Kalenderîlikten ayrılmıştır. Kutbeddin Haydar elbise olarak keçe giyer ve yalınayak dolaşırdı. Kenevir yapraklarını veya esrar sakızını vecde ulaştırıcı bir araç olarak görür ve kullanırlardı. 15. ve 16. yüzyıllara ait tahrir defterleri üzerinde yapılan incelemelerden anlaşıldığına göre Kalenderî ve Haydarî zaviyeleri Orta ve Doğu Anadolu'da yoğunluk kazanırken batıya doğru gittikçe azalmaktadır. Söz konusu dönemde Ankara, Aksaray, Ayasuluk, Bayburt, Beyşehir, Birgi, Bursa, Erzincan, Erzurum, Hısn-ı Keyf, Kastamonu, Kırşehir, Larende, Niksar, Milas, Konya, Kayseri, Tokat, Zile kazalarında Kalenderî ve Haydarî dervişlerinin toplanma alanları olan 'Kalenderhâne' ve 
'Haydarîhâne'lerin çokça bulunduğu ve hepsinin de faal olduğu anlaşılmaktadır (Gülten, 2012, s. 39).

\subsection{Vefâîyye}

13. yüzyıl Anadolu'sundaki inanç ve anlayışlar arasında yer bulan Vefâîyye 11. asırda Irak'ta yaşamış Ebu'l-Vefâ el-Bağdâdî (ö.1107) tarafindan kurulmuş bir tarikattır. Tarikat kısa sürede Irak, Suriye ve Anadolu'da yaygınlık kazanmış, İslam'a yeni girmiş kitleler tarafından kabul görmüştür. Vefâîliğin Anadolu'daki en önemli temsilcisi Selçuklu devletini çokça uğraştıran, fiili bir isyan teşebbüsünde de bulunan Baba İlyas (ö. 1240)'tır. Bu nedenle Vefâîyye tarikatına mensup olanlara Babaî de denilmiştir. İktidar gücünü yitirmiş Selçuklu zamanının Anadolu'sundaki ekonomik ve toplumsal olumsuzluklar, bazı iç ve dış siyasi teşvik ve tahrikler, dini kargaşa ve sığlık Baba İlyas'ın isyankâr ve umut aşlayıcı propagandasını cazip hale getirmiştir. Onun görüş ve vaatleri ne yapacağını, neye inanacağını bilemez haldeki Türkmen topluluklarına cezbedici gelmiş, fiili isyana uzanan süreç ustalıkla tesis edilmiştir. Türkmen topluluklarından özellikle Anadolu'ya yeni gelmiş ve henüz yurt tutamamış, aç ve sefil halde dolaşan, maruz kaldıkları zorlukları değiştirmek veya siyasî iktidarı ele geçirerek devlete bizzat sahip olmak yahut devleti zorlayarak isteklerini kabul ettirmek isteyen Türkmen toplulukları isyana isteyerek iştirak etmiştirler. Ayrıca Türkmenlere yönelik kötü idare ve haksız uygulamalarda başı tutan Sultan II. Gryaseddin Keyhüsrev ve veziri Sadettin Köpek gibi devlet yöneticilerinin olumsuz tutum ve davranışları bazı Türkmen toplulukları için isyanı zorunlu hale getirmişti. Baba İlyas ise çoktandır organize ettiği isyanı için tüm bu şartları çok başarılı şekilde kullanıp sonunda tarihe Babaîler İsyanı olarak geçen toplumsal ayaklanmayı gerçekleştirmiştir.

Babaî isyanında dikkat çeken husus, Baba İlyas yönetimindeki Türkmenlerin, Selçuklu iktidarına karşı hoşnutsuzluklarını ifade ederken dinî bir dil kullanmalarıdır. Esasında tamamen ekonomik, siyasi nedenlerden kaynaklanan isyan ilginç bir şekilde dini bir niteliğe büründürülmüştür. İsyanı organize eden propagandistler konuşmalarında, yoğun bir şekilde olmak üzere, sultanın sefih ve zalim bir kişi olduğuna, vaktini devlet işleri yerine içki meclislerinde geçirdiğine, devlet adamlarının da kendisine uyup halka zulmettiklerine, dolayısıyla Allah'ın yolundan uzaklaştıklarına ve aynı zamanda Peygamberin ve halifelerin yolunu takip etmediklerine yer vermişlerdir (İbn Bîbî, 1996, s. II/50). Mevcut olumsuz şartlardan bunalmış Türkmen toplulukları, bu propagandaların etkisiyle Baba İlyas'ı, siyasi ve askeri bir lider olmaktan daha çok, din dışı örf ve adetlerin yayıcısı olarak görülen siyasal iktidarın baskılarından insanları kurtaracak bir mehdi gibi algıladılar. Bu nedenle Baba İlyas'a tam bir imanla bağlandılar. 1239-40 yılında Samsat civarında başlayan isyan, daha sonra Amasya çevresine sıçradı. İsyan iki buçuk ay sürdü ve bu süreçte Babaîler, Selçuklu kuvvetlerini üst üste on iki kez yenilgiye uğrattılar. Kendilerine Baba İlyas'tan dolayı Babaî denilen isyancılar iktidarı ele geçirebilmek için Konya'ya doğru ilerlediklerinde Necmeddin Behramşah komutasındaki 60.000 kişilik Selçuklu ordusunca, Kırşehir'in Malya sahrasında karşılandılar. İlginçtir, Necmeddin Behramşah'ın ordusunun önemli bir kısmı paralı Frank askerlerinden oluşuyordu. Çünkü Baba İlyas'ın propagandaları ancak onları etkilememişti. Malya'da gerçekleşen savaş çok kanlı sonuçlandı ve Babaîler tamamıyla katledildiler. Anadolu'nun büyük bir 
kısmını etkileyen ve kanlı şekilde zorla bastırılabilen isyanı takiben Vefâîyye mensupları için Anadolu cazip bir yer olmaktan çıktı. Vefâî şeyh ve dervişleri kendilerine yönelik takibatta kurtulabilmek amacıyla merkezî otoritenin daha zayıf olduğu uç bölgelerine göç ettiler. 1243 yılındaki Kösedağ yenilgisi sonrasında Anadolu Selçuklu Devleti'nin yıkılma sürecine girmesiyle daha bağımsız hareket etmeye başlayan uç beyliklerinin idareleri altında güven içinde yaşadılar. Çünkü uç beylikleri ile olumlu ilişkiler kurdular. Bu ilişkiler karşılıklı menfaate dayanıyordu. Zira uç beylikleri bu tür kesimler sayesinde taraftar kitleler bulurlarken, bu kesimler ise beyliklerin koruyucu kanatları altınca varlıklarını sürdürme imkânı elde ettiler. Babaî isyanının en önemli olumsuzluğu, Anadolu'yu Moğol istilasına hazırlamasıdır. İsyan nedeniyle hepten güç kaybetmiş Selçuklu devleti Moğol karşısında çaresiz kalmıştır.

\subsection{Kalenderîlik}

Anadolu'da önemli bir miktara ulaşan kitleleri yanına toplamayı başarmış tasavvuf/inanç ekollerinden birisi ve hatta en önemlisi Kalenderîliktir. Kalender kelimesinin Farsçada "iri yarı, kaba" anlamındaki "kalanter" (Yazıcı, 1968, s. 786) veya Farsça "kalan" kelimesiyle "ender" ekinden oluştuğu ve "ağır yük taşıyan, ağır yük altına girmiş bulunan" manasına geldiği yahut Arapça "ekall" kelimesiyle Farsça "ender" ekinin birleşiminden teşekkül ettiği ve "az, önemsiz" anlamında kullanıldığı düşünülmektedir. Öte yandan Kalenderin Sanskritçe "kalandara" (Kanun, nizam dışı, düzeni bozan) kelimesinden alınmış olabileceği de ifade edilmiştir (Ocak, 1999, s. 6). Tüm bu anlamlar ise Kalenderîleri başarılı bir şekilde tanımlamaktadır.

Moğol istilası ile Anadolu'ya yoğun olarak gelen tasavvufi zümrelerin en etkilisi Kalenderîlerdir. Bunların bir kısmı Moğol belasından kurtulmak için gelirken bir kısmı ise Moğollarla birlikte gelmiştir. Çünkü Kalenderîler kendi içlerinde farklı alt gruplara bölünmüş durumdaydı. Moğollarla iyi ilişkiler kuranlar olduğu gibi, Moğollara kayıtsız kalanlar da vardı. Kalendirîliğin ilk olarak Orta Asya ve Fars bölgelerinde ortaya çıktığı düşünülmektedir. 12. ve 13. yüzyıllarda, Moğol istilası sonucu yaşanan siyasî ve toplumsal olayların etkisiyle tarikat teşkilatlanarak hızla yayılmıştır. Kalenderîlerin Anadolu'ya ilk geldikleri tarih tam olarak bilinmemekle birlikte 13. yüzyılın ilk çeyreğinden itibaren bölgede varlıklarını hissettirdikleri bilinmektedir. Yesevîlik, Haydarîlik, Vefâîlik gibi tarikatlar aracılığıyla veya görünümü altında Anadolu’ya giren Kalenderîlik, bu coğrafyada çok nüyük bir etkiye sahip olmuştur. Anadolu'da Osmanlı öncesi dönemde, Aybek Baba ve Barak Baba adlı iki Türk şeyhi Kalenderîliğin yaygınlaşmasında ve yerleşik hale gelmesinde önemli rol üstlenmişlerdir. Bu şeyhler Anadolu Selçuklu Devleti'nin son dönemlerinde Moğollar ile ittifak kurarak, Selçuklular aleyhinde hareket ettiler. Hayatı hakkında yeterli bilgi bulunmayan Aybek Baba, Babaî çevreleriyle ilişkisi içerisinde olup, Moğollarla işbirliğinin faydalı olacağına inanan bir kişi olarak bilinmektedir (Ocak, 1992, s. $68)$.

Kalenderîlik, kurucusu Ebu Sa'îd-i Ebi'l-Hayr olan Melâmîliğin Türkmen babalarınca uyarlanmış basit, sade şeklini temsil etmektedir (Karamustafa, 2017, s. 129). Melâmîlik anlayışından doğmuş, fakat tarihî süreç içerisinde başka inançların ve anlayışların etkisinde kalarak kökeni Melamîlikten büyük oranda 
uzaklaşmıştır. Kalenderî tarikatının kuruluş aşamasında karşımıza çıkan isim Şeyh Cemaleddin Sâvî'dir. Cemaleddin Sâvî, Şam'da ikamet eden Şeyh Osman-ı Rûmî'nin zaviyesinde bir süre ikamet ettikten sonra tuhaf inanç ve yaşantı sahibi bir şahsiyet olan Celal-i Dergezînî ile tanışmış ve onun etkisiyle dünyadan el etek çekerek mezarlıkta yatıp kalkmaya başlamıştır. Kalenderîlik inancında Hind-İran mistik unsurların oldukça güçlü etkisi vardır. Budist, Zerdüştî ve Maniheist unsurlara sahiptir (Ocak, 1999, s. 5-11). Kalenderîlik, Melamîlikten gelen etkiyle içinde yaşadığı toplumun egemen kural ve hayat tazının dışında kalmaya büyük önem veren bir anlayışın etkisiyle mal-mülk edinme başta olmak üzere dünyevî şeylere uzak ve kayıtsız kalmayı önemseyen, yoksulluğu yücelten ve buna uygun bir yaşayışı ön plana çıkaran bir tasavvuf ekolü olarak anlam kazanmaktadır. Bu inanç, Moğollara kayıtsız kalmalarını ve hatta doğrudan veya dolaylı bir şekilde desteklemelerinin sebebini açıklayan önemli bir özelliktir. Zira onlar için yönetimin kimde ve nasıl olduğu hiç önem ifade etmemektedir.

Kalenderîlerin görünüşleri toplumun bütünü tarafindan yadırganan tuhaflıklar içermekteydi. Kalenderî dervişleri, yoksulluğu yüceltmenin göstergesi olarak kıldan dokunmuş ve cavlak adı verilen kaba yün çuvallar giyerlerdi. Saç, sakal, bıyık ve kaşların ustura ile kazındığı "çahar darb" denilen bir ritüelin gereğine uymayı önemserlerdi. Üzerlerinde dilenci çanağı ve derviş değneği, balta, deri torba, büyük tahta kaşıklar ve aşık kemikleri taşırlardı. Bu tarz, Melâmîlik'te vurgulanan toplum tarafından dışlanma anlayışının bir tezahürüydü. Tuhaf görünüşleriyle toplumda tiksinti yaratmayı ve bu şekilde toplumdan dışlanmayı sağlama amacı içerisindeydiler. Bu amaca uygun olarak, çıplak veya yarı çıplak dolaşırlardı (Ülken, 2003, s. 75). Şu da bilinmektedir ki, Melamîlerde cinsellik ilahi aşktan uzaklaştırıcı bir unsur olarak görülmüş ve aşağılanmıştır (Köprülü, 1996, s. 47-52). Bundan dolayı evlenmemek Kalenderîliğin de önemli bir prensibi olarak kabul edilmiştir. Ancak bu bazı sapkınlıkları engellememiştir. Hint keneviri çiğnemeyi ve toprak üzerinde uyumayı tipik davranışlar olarak benimsemiş bazı Kalenderîler arasında sapkın (Karamustafa, 2011, s. 17) bir şekilde genç erkeklere ilgi duyanlara da rastlanmıştır. Ayrıca Allah'ın cemalini güzel delikanlıların yüzünde temaşa etme düşüncesi sahip Kalenderîler bunu mahbubperestlik (cemâlperestlik) erkânı olarak nitelerlerdi (Ocak, 1992, s. 171).

Kalenderîlikte yerleşik hayat bütün kurumları ile reddedilmiş, çalışmak, ev-bark edinmek gibi toplumsal yapıya uyumlu olmayı gerektirecek uygulamalar aşağılanmış, gezgin ve başıboş şekilde yaşamak temel prensip haline getirilmiştir. Tarihi kaynaklar Kalenderîleri, helal veya mubah gibi kavramları dikkate almayan, harama riayet etmeyen, namaz kılmayıp açıktan olmasa bile gizlice oruç yiyen ve şarap içen, hiçbir şekilde küfre girmekten çekinmeyip, dilencilikle geçinen ve çalışmayan tembeller olarak görüp, halkın sırtında geçinen kişiler olarak tasvir etmektedir (Akkuş, 2014, s. 121). Molla Câmî (ö.1492) Melâmîlikle kıyaslayarak zamanının Kalenderîliğini şöyle açıklamıştır: "Melâmetiyye'ye benzedikleri muhakkak olan Kalenderîler; îmar ve tahribe iltifat etmezler, ekseri çabaları toplumun âdab ve âdetlerine karşı olup kayıtlardan bağımsızdırlar. En büyük sermayeleri hallerden vazgeçmek ve kalb huzuru (temizliği)'dur. Zâhidlik, âbidlik merasimleri onlarda yoktur. Ekseriyetle nafile ibadetler-Melâmetîlerde olmasına ră̆men- onlarda görülmez. Amellerle yücelmek hususunda fazla 
riayetkâr değillerdir, farzdan gayrı vazifelerle uğraşmazlar. Melâmetîyye ile aralarında riyadan kaçınma hususunda benzerlik, ibadetlere riayet hususunda mezkûr farklılıklar vardır” (Molla Camî, 1981, s. 40-41). Melamîlik konusunda müstakil bir eser yazmış Abdulbaki Gölpınarlı ise Melâmîlik-Kalenderîlik karşlaştırmasını yaparken Melâmîlerin konuşmalarında iyiliğe, ihsana imkân ölçüsünde yer verip, davranışlarını sözleriyle çelişkiye düşürmemeye çalışmalarına karşılık, Kalenderîlerin Melâmîlerin tam tersine olacak şekilde örf ve âdetlerin icaplarına uymayan, ibadetleri bir yana bırakıp gününü gün eden kimseler olduğunu ifade etmiştir (Gölpınarlı, 1931, s. 15-16). Kalenderîlerle ilgili olarak şunu da not etmek gerekiyor: Anadolu Selçukluları döneminde Anadolu'da büyük bir güç ve nüfuz elde eden Kalenderîler Osmanlı devrinde eski güç ve statülerini kaybetseler de, İslam dünyasının çeşitli zaman ve mekânlarında pek çok değişik isim ve lakaplarla varlıklarını sürdürmüşlerdir (Bağcı, 2020, s. 240-252). Köklerinde Yesevîlik ve Horasan Melamîliği bulunan Kalenderîlik ve Haydarîlik Anadolu'ya Moğol istilası sonrasında gelmiş tarikatlar olarak Anadolu'nun dini tarihinde derin izler bırakmışlar, 14-16. yüzyıllarda Bektaşîlik şalı altında eriyip kaybolmuşlardır (Köprülü, 1981, s. 160-171).

\subsection{Kübrevîlik}

Necmeddîn Kübrâ tarafindan kurulmuş ve ona atfen Kübrevîlik olarak isimlendirilmiş bir tasavvuf ekolüdür. Necmeddîn Kübrâ ilim merakıyla zamanında en ünlü ilim merkezleri durumunda olan Nişâbur, İsfahan, Hemedân, Mekke, İskenderiye, Tebriz, Bağdat, Kerbelâ ve Mağribi dolaşmış ve ismi geçen şehirlerde ilim adamlarından dersler almış, mutasavviflarla görüşmüştür. Necmeddîn Kübrâ'nın ilim tahsili ve tasavvufî eğitimi için şehirler ve ülkeler kapsayan seyahatleri yirmi yaşlarında başlamış, yaklaşık olarak kırk yaşlarında kendi ülkesi olan Harezm'e dönüşüne (1184) kadar devam etmiştir. Ömrünün geri kalan kısmını bu topraklarda geçirmiş ve irşat faaliyetleriyle meşgul olmuştur. Necmeddîn Kübrâ'nın ölümüyle ilgili yaygın rivayete göre, 1221 senesinde Moğollar'ın Harezm'in merkezi Gürgenç'te gerçekleştirdikleri katliam sırasında müritleriyle şehri savunurken şehit olmuştur. Kaynaklarda Cengiz Han'ın şehri terk etmesi için izin verdiği fakat Necmeddîn Kübrâ'nın şehir yakılıp yıkılırken ve Müslüman kanı dökülürken hayatının bağışlanmasını kabul etmediği, Moğol güçlerine karşı yanındaki altı yüzü aşan müridiyle büyük bir direniş gösterip savaştığı ve aldığı bir ok nedeniyle vefat ettiği anlatılmaktadır. Necmeddîn Kübrâ'nın ve kendisinden sonra halifelerinin yoğun irşat faaliyetleri sayesinde tarikat, 13. ve 14. yüzyıllarda Orta Asya'dan Hindistan ve Irak'a kadar geniş alanda yaygınlık kazanmıştır. Necmeddîn Kübrâ'nın eserlerinde Muhyiddîn İbnu'l-Arabî’nin görüşlerine hiçbir atıfta bulunmamasına rağmen İbnü'l Arabî'ye ilgi duyulması onun halife ve takipçilerinin önemli özelliklerinden birisi olmuştur. Benzer şekilde on iki imama gösterilen saygı ve itibar birkaç nesil sonra bazı Kübrevîleri Şiî olmaya sevk etmiştir. Sonraki dönemlerde Kübrevîliği Şiîlik ile uzlaştırma çabaları görülmüşse de Necmeddîn Kübrâ kesinlikle (Algar 2000, s. 500-501) Sünnî anlayışa mensup birisiydi.

Tasavvufî kişiliği daha çok Kübrevî gelenekleriyle şekillenen Necmeddîn Dâye, bu tarîkatın Anadolu'da yayılmasında ve gelişmesinde etkili olmuştur. 1177 yılında İran'ın Rey şehrinde dünyaya gelen Necmeddîn Dâye, Diyarbakır, Malatya, Kayseri ve Sivas'ta ikamet etmiş, inanç ve görüşlerini buralarda 
yaymıştır. Anadolu'da bir müddet kaldıktan sonra pek çok şehir dolaşan Dâye sonunda Bağdat'a yerleşmiş ve hayatının geri kalan bölümünü burada eser yazmakla geçirmiştir. Kaynakların çoğu Dâye'nin çileli hayatının 1256 yılında Bağdat'ta, Moğollar'ın Bağdat'ı kuşatmasından iki sene önce sona erdiğini belirtmektedir. Necmeddîn Dâye, aşk ve cezbe yolunu takip eden bir sûfî olması ve eserlerindeki çoğu coşkun ifadelerine rağmen ehlisünnet görüşüne büyük önem vermiş ve Sünnî tasavvufu benimsemiş bir sûfî olarak bilinmektedir.

\subsection{Ahilik}

Ahilik esasen fütüvvet teşkilatının Anadolu'daki versiyonunu temsil etmektedir. Fütüvvet, Osmanlı öncesi İslam toplumlarında varlığını sürdüren bir zihniyet yapısını ve çok yönlü faaliyet alanını ifade etmektedir. Ahilik Anadolu Selçukluları zamanında kurulmuş Türk fütüvvet hareketidir. Ahilik, fütüvvet teşkilatı gibi bütün İslam dünyasına yayılmamıştır. Sadece Anadolu'da ve Türk muhitlerinde vücut bulmuştur. Dini ve askeri yönü olduğu gibi bir çeşit meslek örgütlenmesi ve dayanışması özelliklerine de sahiptir. Fütüvvetin Osmanlı'daki karşılığı olan Ahilik özellikle ilk zamanlarda benzer özellikler göstermiş ve din, ahlâk, vicdan ile askeri, ekonomik, sosyal amaç ve çabalar arasında bir bütünlük oluşturma gayesinin ürünü olarak doğmuştur. Bu zihniyet ve yapı, Osmanlı Devleti'nin özellikle kuruluş ve klasik dönemlerinde daha çok da ticaretin, zanaatların ve sanatların işleyişinde oldukça önemli işlevler üstlenmiştir.

Ahiler, özellikle Moğol istilası sırasında, bu istilayı bertaraf etmek için çabalayıp, firsat bulduklarında fiili mücadele etmekten de geri durmadılar. Osmanlı'nın kuruluş döneminde ise toplumsal bir yardımlaşma ve dayanışma anlayışının etkisiyle şehir ve kasabalarda yoğun faaliyetler yürüttüler. Bölgenin asayişini temin, bazı bölgelerde mahalli idareyi yürütme, iktisadi işleri düzenleme ve çeşitli sanat ve meslekleri (dönemin isimlendirmesiyle "hirfetleri": Kunduracılık, duvarcılık, demircilik, marangozluk, dokumacılık vb. küçük el sanatlarına verilen ad) gerçekleştirme gibi Osmanlının kuruluş yıllarında oldukça önemli olan bir dizi sorumluğu yerine getirdiler. Ahiler, Anadolu'nun tamamının fethini takiben Balkanlara ve Kırım’a yönelerek en küçük yerleşim birimlerine kadar uzanan bir örgütlenme üzerinden faaliyetlerine devam ettiler. Yaygınlıklarına ve dinamizmlerine tanık olması itibarıyla, 14. yüzyılın ilk yarısında Anadolu'yu gezen Afrikalı Müslüman seyyah İbn Batuta (ö. 1369)'nın anlattıkları oldukça önemlidir. İbn Batuta, neredeyse uğradığı her şehir ve köyde ahilerle karşılaşmış ve onlardan seyahatname niteliğindeki eserinde şöyle bahsetmiştir: "Ahiler Anadolu'da yerleşmiş bulunan Türkmenlerin yaşadıkları her vilayette, her şehirde ve her köyde bulunmaktadırlar. Memleketlerine gelen yabancilara yakın ilgi gösterirler, yiyeceklerini, içeceklerini temin ederler, diğer ihtiyaçlarını karşılamakta itina gösterirler. Öte yandan bulundukları yerlerdeki zorbalart yola getirir, herhangi bir sebeple bunlara iltihak eden katilleri ortadan kaldırırlar. İşte bu gibi hususlarda bunların dünyada eşi benzeri yoktur" (İbn-i Batuta, 1993, s. 194, 195).

Ahiliğin Anadolu'daki ilk oluşumunda etkili olan ve liderliğini üstlenen şahsiyet Ahi Evran ismiyle tanınan Mahmud bin Ahmed'dir. Ahi Evran 1171'de Azerbaycan'ın Hoy kasabasında doğmuştur. Doğmuş olduğu kasabanın isminden dolayı "Hoî" olarak da anılmıştır. Künyesi hakikatlerin babası anlamına gelen 
Ebû'l-Hakâik, lakabı ise İslam'a ve Müslümanlara yaptığı hizmet ve katkılardan dolayı Nasîruddîn'dir. Çocukluğu ve ilk tahsil yılları memleketi Azerbeycan'da geçmiştir. Gençliğinde Horasan ve Maveraünnehir bölgesine giderek orada eğitim görmüş, dönemin önemli âlim ve düşünürlerinden ders alarak yetişmiştir. İbn-i Sina, Sühreverdi el-Maktul ve Fahreddin Razi'nin eserlerini iyi bir şekilde tetkik etmiş ve hatta bu şahsiyetlerin bazı eserlerini Farsça ya tercüme etmiştir. Özellikle tefsir, hadis, kelam, fikıh ve tasavvuf gibi ilimler yanında felsefe ve tıp sahasında da ileri düzeyde ilme sahip olmuş ve bu konularda eserler vermiştir.

Ahi Evran, 13. yüzyıl başlarında Moğol istilasının önünden kaçarak önce Bağdat'a gelmiş ve bir süre burada kalmıştır. Bir hac yolculuğu esnasında Fahreddin Râzî̀nin talebelerinden Evhadüddin Kirmânî (ö. 1238) ile tanışmış, ondan çok etkilenerek onun talebeleri arasına katılmıştır. Ahi Evran, Bağdat’ta iken fütüvvet teşkilatının ileri gelen şeyhleri ile görüşmeler yapmış ve teşkilatın misyonunu benimsemiştir. Hocası Evhadüddin Kirmânî ile birlikte 1206 yılında Kayseri'ye yerleşen Ahi Evran geçimini debbağlık (dericilik) yaparak temin etmiş, bu yüzden debbağların piri olarak tanınmıştır. Ahi Evran Kayseri'de ikameti sırasında çevresine toplanan insanları örgütleyip Ahi teşkilâtını kurmuştur.

Ahi Evran ve Ahiler, Türkmenler tarafindan "Ulu Alaaddin" diye anılan ve Ahiliğin Anadolu'da yayılmasında önemli katkıları olan Alaaddin Keykûbât'ın oğlu Giyaseddin Keyhüsrev tarafindan öldürülmesi üzerine yeni sultana ve vezir Sadettin Köpek'e destek vermediler. Hatta yer yer itiraz ettiler. Bunun üzerine pek çok Ahi ve Ahilere yakın Türkmen zümresi öldürüldü, bazı ileri gelenler tutuklatip hapsedildiler. Hapse atılanlar arasında Ahi Evran da vardır. Ahi Evran, beş yll (1240-1245) zindan da kaldı. Giyaseddin Keyhüsrev'in ölümü üzerine (1245), saltanat naibi sıfatıyla idareyi ele alan Celâleddin Karatay, hapisteki bütün Ahileri, bu arada Ahi Evran'ı serbest bıraktı. Ahi Evran Denizli'ye giderek bir yll burada ikamet ettikten sonra, Sultan II. İzzeddin Keykavus'un daveti üzerine Konya'ya gitti. Konya'da Mevlevîlerin Moğollar ile ilgili tutumunu desteklememesi üzerine rahatsız edildiğinden Kırşehir'e geçti (1247). Kırşehir'e geçmesinde, daha önceden tanışıp görüştüğü Hacı Bektaş Velînin Kırşehir'de yaşıyor olmasının etkisi olduğu düşünülmektedir. Vilâyetnâme'de, her iki şahsiyetin pek çok kez bir araya geldiği belirtilmekte ve aralarında geçen bazı konuşmaları detaylı bir şekilde anlatılmaktadır. Ahi Evran ve Hacı Bektaş'in dostluğu oldukça ileri düzeyde olduğu için Alevi-Bektaşî geleneğinde bu iki şahsiyet, birbiriyle musahip olarak kabul edilmiştir. $\mathrm{Bu}$ yüzden olmalı ki Ahi Evran'ın öldürülmesinden sonra eşi Fatma Bacı, Hacı Bektaş Velî̀nin yanına giderek onun himayesinde ve onun çevresinde hayatını sürdürmüştür.

Ahi Evran Kırşehir'de kaldığı süre içerisinde bir yandan Ahi teşkilatını geliştirmek için çalışırken, aynı zamanda Moğol istilasına karşı fikri ve fiili mücadele vermiştir. Hiçbir zaman ve hiçbir şekilde Moğollara karşı olumlu duygu ve düşünceye sahip olmamasıyla, döneminin diğer pek çok tasavvuf ekolünden ayrılmıştır. Moğolları işgalci olarak görmüş ve fiili mücadeleyi zorunlu olarak görmüştür. Bu ise Moğolları çok rahatsız etmiştir. Moğollar, Ahi Evran'ın Ahi ve Türkmenler üzerindeki nüfuzunu kendileri için ciddi bir tehdit olarak algıladıkları için Ahi Evran'a karşı özel bir düşmanlıkları olmuştur. Moğollar, Ahililerin bazı Türkmenlerle beraber kendilerine karşı harekete geçmelerini 
fırsat bilerek, kendileri için tehlike gördükleri Ahi Evran'ı ve Ahi teşkilatını yok etmeye karar vermekte zorlanmadılar. Böylelikle Ahilerle Moğollar arasında fiili savaş başlamış oldu. Moğollara yönelik en güçlü direniş, Ahi Evran liderliğinde Kırşehir'de gerçekleşti. Ahi Evran ve pek çok Ahi, Moğolların Kırşehir emiri Nurettin Caca tarafindan öldürüldü (1264). Ahi Evran şehit edildiğinde 93 yaşındaydı.

\subsection{Bektaşîlik}

Bektaşîliğin kurucusu kabul edilen Hacı Bektaş Velî, Horasan'ın Nişabur kentinde dünyaya gelmiştir. Vilâyetnâme'ye göre asıl adı Bektaş'tır. "Bektaş", kelime olarak "bendeş" ve "beğdeş" gibi eski Türkçe bir sözcük olup "eşit", "müsâvî", "müâdil”, "misil” anlamlarına gelmektedir. Hacı Bektaş Velî’nin doğum ve ölüm tarihiyle ilgili çeşitli kaynaklarda farklı bilgiler yer alsa da 13. yüzyılda yaşadığı kesindir. Mevcut bilgiler 1209-1270 tarihleri arasında yaşadığını göstermektedir. Erken dönemden itibaren Ahmed Yesevî’nin düşünce çizgisinde yer almış, Ahmet Yesevi'ye olan bağlı̆̆ı nedeniyle Vilâyetnâme'de Hoca Ahmet Yesevi ile görüştüğü dile getirilmiştir. Bu elbette ki tarihsel olarak mümkün değildir. Ancak hayali olarak kurulan bu fiziki irtibat, Hacı Bektaş Velî’nin Ahmed Yesevi'ye yönelik muhabbet ve saygısının bir yansıması olarak anlam kazanmaktadır. Hacı Bektaş, çocukluğundan Anadolu'ya gelişine kadar geçen süre zarfında zengin bir kültürel çevrede yetişmiş, üst düzey bir eğitim almıştır. Tasavvufi yönü, babası tarafindan, Ahmet Yesevî’nin halifelerinden Lokman Parende'ye teslim edilmesi ve onun himayesinde Yesevîlikten feyz alarak yetiştirilmesi ile oluşmuştur. Uzun yıllar Nişabur'da kalmıştır. Tarihi kaynaklarda, Hacı Bektaş'ın Nişabur'dan ayrıldıktan sonra Amasya, Kayseri ve Sivas'a gittiği, daha sonra Kırşehir yakınlarındaki Sulucakarahöyük'e gelip buraya yerleştiği belirtilmektedir. Hacı Bektaş'ın Anadolu'ya kaç yaşında ve kaç yılında geldiği konusunda kesin bilgi yoktur. Anadolu'ya geldiğinde Baba İlyas ile görüştüğüne ilişkin bilgiler varsa da onun isyanına iştirak etmemiştir (Melikoff, 2010, s. 99-100). Celaleddin Rumi ile haberleştiklerine dair bazı bilgiler mevcutsa da detayı bilinmemektedir. Ancak bunun çokta dostane olduğunu söylemek mümkün görünmemektedir. Buna karşılık Moğollara fiilen başkaldıran Ahi Evran ile yakın dost olduğu, sıklıkla görüştükleri kesindir (Firdevs-i Rumi, 2007, s.87b-88b). Hacı Bektaş ve dönemindeki taraftarlarının Ahi Evran ve ahilikle ilgileri sebebiyle Bektaşilik’teki tarikata giriş ayininin, eşik öpme ritüelinin, kuşak bağlama töreninin, aynı kâseden şerbet içme âdetinin, kıyafetle ilgili özelliklerin, törenlerde okunan duaların tamamıyla ahilikten alınmış olması şaşırtıcı değildir (Coşan, 2019, s. XXVII). Zira Hacı Bektaş ile Ahi Evran ilişkisi kişisel bir dostluğun ötesindeydi. Hacı Bektaş Velî̀nin ilk arkadaşları aynı zamanda birer Ahî idiler. Hacı Bektaş Velî, Anadolu'da otuz altı yıl yaşadı ve tüm bu süreyi yoğun bir şekilde irşat faaliyetleriyle geçirdi. Aşıkpaşazade Tarihi'nde ifade edildiği ve Velâyetnâme'nin de tanıklık yaptığı üzere söz konusu bu süre zarfında Hacı Bektaş'ın çevresinde Türkmen gaziler, ahiler ve abdallar toplandılar. Daha da dikkat çekeni ise Hacı Bektaş'ın yanında yer alanlardan birisi de Bacıyan-ı Rum'un öncülerinden Hatun Ana'dır (Aşıkpaşazade, 1970, s. 222; Firdevs-i Rumi, 2007, s. 28b-31a).

Hacı Bektaş hakkında döneminin kaynaklarında herhangi bir bilgi olmaması dikkat çekicidir. Hakkındaki tüm bilgiler sonraki kuşaklara aittir. Bu ise lehinde 
ve aleyhinde görüşlerin yaygınlaşmasına yol açmıştır. Onu İslami çizginin önemli bir temsilcisi olarak görenler olduğu gibi, İslam dışı bir çizgiye oturtmaya çalışanlar da olmuştur. Genel bir tanımlamayla ifade etmek gerekirse, Ocak'a göre (2018, s. 163), Hacı Bektaş, Yesevîlik ve Kalenderîliğin karışımından oluşan Haydari tarikatının bir mensubu olarak Anadolu'ya gelmiştir. Daha sonra Baba Illyas-ı Horasani çevresine girerek Vefâilik tarikatına intisap etmiştir. Bektaşîlik tarikatını kendisinin kurmadığı ise muhakkaktır.

Şurası kesindir ki Hacı Bektaş, Anadolu'ya egemen "bunalım döneminde", Moğolların önünde kaçarak Anadolu'ya doluşmuş ve İslam'ı bilmeyen Türkmen topluluklara, onları İslami çizgiye çekecek kendine özgü bir İslami anlayış ile yaklaşmıştır. Mensubu olduğu topluluk bile bundan uzak değildir. Hacı Bektaş Velî de, Moğollar sebebiyle muhtemelen kendisine bağlı bir Türkmen oymağının başında Anadolu'ya gelmişti. Türkmen oymakları, o dönem de genellikle başlarındaki şeyhin/önderin ismiyle anılmaktaydı. Hacı Bektaş Velî̀nin beraberinde de kendi ismini taşıyan Bektaşlu oymağı bulunuyordu. Nitekim Osmanlı tahrir defterlerine bakıldığında, Hacı Bektaş Velî̀ye bağlı geniş bir Bektaşlu oymağının bulunduğu görülmektedir (Ocak, 1996, s. 455). Bu boy ve oymakların tamamı, o koşullarda henüz tam olarak Müslüman olmamış ve İslam inancını da özümseyememişlerdi (Mélikoff, 1998, s. 2). Hacı Bektaş'ın bu topluluklara yöneldiği ve onları İslami bilgilerle donatmaya çalıştığı anlaşılıyor. Bunu yaparken bu toplulukların İslam'a aykırı olmayan kabul ve inançlarından da yararlandığı anlaşllyyor. Örneğin İslam öncesi kültürde yaygın olan "kam" anlayışı ile birlikte "ataya saygı" geleneğini ön plana çıkardığı ve dile getirdiği düşüncelerin bir parçası kılmaya çalıştığı görülmektedir (Eröz, 1992, s. 12). Bu nedenle kamlıkta bulunan babadan oğula geçen kutsal görev anlayışının, benzer şekilde Bektaşilikte de varlığını koruması bir tesadüf değildir. İçinde bulunduğu toplumsal şartlarda dış görünüşe ve ritüellere önem vermemesi önemlidir. Şekilciliğe önem vermeyen bir insan modeli çizmiştir: "Hararet nardadır, sac'da değildir Keramet baştadır, tac'da değildir Her ne arar isen kendinde ara Kudüs'te Mekke'de, Hac'da değildir" (Eyupoğlu, 1998, s.103) diyerek şekil ve ritüellerden önce inanç ve samimiyet üzerinde durmuştur. O, bir yandan "Oturduğun yeri pak et, kazandı̆̆ın lokmayı hak et" (Kutluay, 2000, s. 35 ) diyerek, temizlik, dürüstlük, çalışmak ve helal kazanç konusunda tavsiyelerde bulunurken, diğer yandan yıkıcılığa, zulme, sömürüye ve tembelliğe karşı da tavır koyarak düzen ve barışın devamını sağlamaya çalışmıştır. "Ayă̆a kalkarsan hizmet amacıyla kalk, Ĕ̆er konuşacaksan, hikmet ile konuş ve oturacağın zaman, saygı ile otur" (Kutluay, 2000, s. 35) sözleri ile toplumda birlik ve dirliğin sağlanması, huzur ve barış içinde yaşamanın önemini dile getirmiştir. "Gelin canlar bir olalım", "Bir olalım diri olalım, iri olalım" (Kutluay, 2000, s. 35, 36) çağrısılla "bunalım ortamından" kurtuluşun yolunu göstermeye çalışmıştır.

Hacı Bektaş Velî, Ahi Evran gibi Moğollara fiilen başkaldırmadı. Ancak Kalenderîlerin bazıları gibi Moğolların adamı da olmadı. Mevlevîler gibi, isterse siyaseten olsun, Moğollarla dostane ilişkiler de geliştirmedi. Fakat mevcut bilgilerden anlaşıldığına göre Moğollara yönelik sözlü tepkilerde bulunmaktan da geri durmadı. Ancak gönlünden geçenin Moğol istilasına son vermek olduğu kesindir. Ahi Evran ile olan özel dostluğu bunun en güçlü göstergesidir. Mevcut şartlarda Ahi Evran gibi fiili bir başkaldırı gerçekleştirmemişse de engel de 
olmamış veya fiili başkaldırıyı yanlış bulduğunu ifade etmemiştir. Üstelik dönem Ahilerinin bazıları aynı zamanda Bektaşi'ydiler ve bunlar Ahi Evran liderliğinde fiilen başkaldırdılar. Hacı Bektaş bunlara engel olmadı. Bacıyan-ı Rum'un lideri konumundaki Fatma Bacı'nın (Kadıncık Ana) durumu da önemlidir. Fatma Bacı, Kösedă̆ yenilgisinden sonra Kayseri'nin Moğollar tarafından istilası sırasında esir alınmış ve 18 yıl zindana atılmıştır. 1259-1260 yılında Sahip Fahreddin Ali'nin sulh için Hülagu ile görüşmesini takiben serbest birakılmıştır (Muhammed Sivasî, 2008, s. 182-184). Fatma Bacı serbest kalınca Hacı Bektaş’ın yanına gitmiş ve Bacıyan-ı Rum'un lideri olarak faaliyetlerine devam etmiştir. Hacı Baktaş'ın hem Ahi olan müritlerine hem de Fatma Bacı'yı Moğol karşıtlığından engellemeye çalıştığına ilişkin herhangi bir bilgi mevcut değildir. Bunlara ilaveten Hacı Bektaş'ın Anadolu'da Kübrevî şeyhi ve aynı zamanda Moğol karşıtı Necmü'd-din-i Daye ve Ekberîlerin Şeyhi Sadreddin Konevî ile yakın dostane ilişki içerisinde olduğu bilinmektedir. Özellikle Sadreddin Konevî ile dostluğu önemlidir. Zira o, Mevlevî Firdevsî̀nin suçlayarak dile getirdiği üzere (Firdevs-i Rumi, 2007, s. 140a-140b) Moğollara açıkça muhalefet etmiş, vasiyetinde gençlerin ve gücü yetenlerin Moğollara itaat etmemelerini dile getirmiş, Moğol istilası altında yaşamaktansa Anadolu'yu terk etmeyi öğütlemiş birisidir (Ergin, 1958, II, s. 82-83). Sadreddin Konevî̀nin Moğolların etkisi dışında kalan uç bölgelerle irtibatını koparmayıp onlarla Moğollarla mücadelenin tarzı konusunda görüştüğünü Aksarâyî açıkça bildirmektedir (Aksarâyî, 2000, s. 69). Yine Sadreddin Konevi'nin Moğollara isyan eden Şerafeddin Hatıroğlu'na gönderdiği bir mektubunda, Şerafeddin Hatıroğlu'na "evladım” diye hitap edip Moğollara karşı isyana teşvik ettiği görülmektedir (Hacıgökmen, 2001, s. 39-49).

Hacı Bektaş'ın çağdaşı olan Ebubekir Niksarî ve Ömer Girîhî iki önemli Cavlakî şeyhi idiler. İkisi de Moğollarla işbirliği halindeydi. Moğolların sözcülüğünü yapıyor ve onlar adına kitleleri etkilemeye çalışıyorlardı. Bu ikisi İbn'ül-Hatîb'in Fustât'ül Adâle isimli eserindeki nitelemeye göre "asla makul kişiler olmayıp, İslam dairesinin dışında kalan aşağılık mahlûk" (Turan, 2010, s. 537-538) kimselerdi. Velâyetnâme'de dönemin birçok şahsiyetinin ismi geçmesine rağmen bu ikisinin isminin geçmemesi oldukça manidardır. Bu durum öncelikle, Hacı Bektaş'ın Moğol yanlısı dinî zümrelerden uzak durma kararlılığının önemli delillerinden birisidir. Bir diğeri ise söz konusu tavrı Moğollara ve yandaşlarına karşı siyasetinin de önemli bir göstergesidir. Çünkü söz konusu kişileri olumsuz olarak da anmamıştır. Anlaşıldığına göre Hacı Bektaş, hiçbir şekilde tasvip etmediği Moğolların ve yandaşlarının tepkisini de çekmeden irşat faaliyetlerine devam etmek istemiştir. Bura da şu da dikkat çekicidir; söz konusu iki Cavlakî şeyhi haklarında olumlu ifadelerle Mevlevî Eflakî'nin eserinde (Eflâkî, 1989, s. 233, 506-507) ismen zikredilmişlerdir. Tüm bunların yanı sıra, Hacı Bektaş'ın Moğollar karşısındaki duruşunun önemli bir göstergesi olarak, Moğol dostu Eflakînnin Hacı Bektaş ile ilgili görüş ve tutumu dikkat çekicidir. Eflâkî, Hacı Bektaş’ "marifetle dolu ve aydın bir kalbe sahip olmasına rağmen şeriata uymamakla" itham etmiş, ne kadar doğru olduğu bilinmemekle birlikte, en azından dönemin Mevlevî bakışını temsil etmesi açısından Celaleddin Rumi'nin Hacı Bektaş'ın doğru yolda olmadığını söylediğini rivayet etmiştir (Eflâkî, 1989, s. 411-412, 539-540). Eflâkî, Celaleddin Rumi'nin, Hacı Bektaş'ı insan yüzlü şeytana benzettiği bir şiirini de nakletmiştir (Eflâkî, 1989, s. 540). 
Hacı Bektaş'ın Moğol karşıtlığı halifelerine de miras olarak geçmiş, bu halifelerden Sarı Saltuk Moğollarla fiilen mücadeleye girişmiştir. Sarı Saltuk'a bağlı Türkmen dervişler Moğollara karşı mücadelede Anadolu Selçuklu Sultanı II. İzzeddin Keykavus'un (1246-1260) yanında yer almışlardır. Moğollara yenildiklerinde ise Anadolu'da kalmak yerine Kırım'a gitmişlerdir. Tüm bunların yanı sıra Nureddin Caca'nın Kırşehir'de gerçekleştirdiği katliamdan sonra Hacı Bektaş'in birçok halifesi gibi Geyüklü Baba ve Abdal Musa ile Osman Gazi'nin kayın pederi Edebali, oğlu Ahi Mahmud, yeğeni Ahi Hasan'ın da bu katliamdan kurtulup uç bölgelere göçtükleri görülmektedir. Bunlar içerisinde Edabali hakkında biraz daha detay bilgi zikretmek gerekirse; Âşık Paşa’nın oğlu Elvan Çelebi, Menakibu'l-Kutsiyye'sinden Edebali'nin Kırşehir'de ikamet etmekteyken Hacı Bektaş'la irtibatlı olduğunu ve daha sonra Söğüt'e gittiğini belirtmiştir (Elvan Çelebi, 1995, s. 168-168).

\subsection{Cavlâkîlik}

Moğollar Anadolu'yu işgale başladıklarında Anadolu'daki farklı din, inanç ve anlayış mensuplarının sürece yönelik tutum ve tavırları birbirinden çok farklı olmuştur. Moğol işgaline fiilen başkaldıran kesimlerin yanı sıra Moğollarla açıkça ve fiilen bir çatışmaya girmeden, İslami inanç ve anlayışı dile getirmelerine rağmen inanç, düşünce ve yaşantıda henüz İslamî ilke ve kalıplara tam uyum sağlamamış toplulukları bilgilendirme ve bilinçlendirme çabası yürütenler de olmuştur. Ahi Evran ve dolayısıyla Ahiler birincisine, Hacı Bektaş Velî ise ikincisine örnektir. Bunların yanı sıra asıl amaçları Moğol işgalini kolaylaştıracak şartları temin olmasa bile, mevcut siyasi otoriteye isyan ederek askeri ve siyasi buhranı daha da derinleştiren ve Moğol işgalini kolaylaştıranlar da eksik olmamıştır. Babaîler ise bu gurupta yer almaktadır. Diğer bazıları ise Moğol veya Selçuklu demeksizin, hangi siyasi veya askeri gücün ne yaptığını dikkate almadan tüm olumsuzluklar karşısında sorumsuz ve tembelce bir hayat tarzını ilkeleştirmişlerdir. Kalenderîlerin önemli bir kısmı bu yaklaşımı temsil etmişlerdir. Onların bu tavırlarıyla belki de parçası olunan buhran ve problemlerin ağırlı̆̆ını psikolojik açından azaltıcı bir çabanın yürüttükleri söylenebilir.

Elbette ki her yaklaşım, anlayış veya ekolün dönemin olumsuz şartları karşısındaki durumları birbirinden çok farklıdır. Ancak tüm bunların yanı sıra bazı kesimler vardır ki bunlar özellikle işgalci Moğollardan yana tutum sergileyerek Moğol egemen gücünün himayesinde güç bulmaya çalışmışlardır. Bunlar Kalenderî ekole mensup olan bazı kişilerdir. Bunlar işgalci Moğollar içinde önemli bir imkân olmuştur. Zira Abbasi ve Anadolu Selçuklularına yönelik saldırılarına başladıklarında Moğolların tek müttefiki Hristiyan topluluklar olmamış, Müslüman topluluklar içerisinden de kendilerine hizmet edecek mezhep mensupları ve tasavvufi zümreler aramışlardır. Bu açından önce Kalenderîler dikkatlerini çekmiştir. Çünkü Kalenderî babaların kendi şamanlarından pek farklı olmadıklarını görmüşler ve onlara yakınlık hissetmişlerdir.

Şamanist olan Moğollar, kültürel anlayış ve inançları icabı harikuladeliklere çok inanıyor, olağanüstü haller sergileyip sihir yapan insanları kutsal kişiler olarak görüyor, onlara çok değer veriyorlardı. Hatta Moğollar bu vasıflara sahip insanlardan korkuyor ve çekiniyorlardı. Bilindiği gibi bahşı ve şamanların 
Moğollar nezdinde yüksek mevkileri vardı. Çünkü bahşıların üstün güçleri bulunduğuna ve onların bu gücünden yararlanmak gerektiğine inanıyorlardı. İslam memleketlerine geldikleri zaman Kalenderî dervişleri de Bahşı ve Şamanlar olarak gördüler. Bahşilere benzeyen Kalenderler, köy köy, kasaba kasaba dolaşıyor, kendilerine şiş batırma, ateşle oynama gibi harikuladelikler sergileyerek halkın ilgisini çekiyorlardı. Söz konusu Kalenderîler bu halleri ile Moğolların dikkatini çekmekte gecikmediler. Bunları kendi şamanlarına benzettiler ve esrarengiz güçleri olduğuna inandılar. Bu nedenle de bunlara itibar ettiler (Akkuş, 2014, s. 123). Bazı Kalenderî dervişlerin Moğollarla ittifak halinde hareket ettiklerini gösteren ilk olay Irak'ta ortaya çıkan Halil bin Bedr el-Kürdî isimli bir şeyhin Halifeye karşı isyanı olmuştur. Bu şeyh kendisinin Rufaî tarikatına mensup olduğunu iddia etmesine rağmen Kalenderî kıyafet giyinip, şarap içen ve haşhaş kullanan birisidir. Moğollarla işbirliği yapan bu şeyh, 1245 yılında Halîfeye karşı başkaldırının liderlerinden birisi olmuştur. Moğollar kendileriyle işbirliğine giden Kalenderî dervişlerinin rehberlik ve ortaklığında itaatkâr olmayan birçok Türkmen topluluğunu kılıçtan geçirmişlerdir. Türkmenlerin katledilişine katılan bu Kalenderî gurubuna karşı Süleyman Şah'a bağlı Türkmenler ise Moğollar dâhil 600 kişiyi öldürmüşlerdir (Turan, 1973, s. 226-227).

Moğollar askeri, dini, idari ve elçilik gibi birçok alanda kullandıkları Kalenderîlerden en çok faydalandıkları, yarar gördükleri nokta casusluk faaliyetleri olmuştur. Anadolu'nun istilası öncesinde başlayarak başta Baycu Noyan olmak üzere Hülâgu Han ve özelliklede Abaka Han dönemlerinde bazı Kalenderî dervişler casusluk faaliyetlerinde yoğun olarak kullanılmışlardır. Kalenderîlerin bu hizmetlerine karşılık Anadolu'da Moğol muhalifi dinî zümrelerin ellerindeki vakıflar, medreseler, tekke ve zaviyeler elinden alınarak Kalenderîlere verilmiştir (Akkuş, 2011, s. 286-307).

Moğollarla işbirliği yapan tarikatların en tipik örneklerinden birisi de esasen Kalenderî olan Cavlâkîlerdir. Cavlakîlerin açıkça Moğol saflarında yer aldıklarını biliyoruz. Baycu Noyan komutasındaki Moğol ordusu Anadolu'yu istilaya başladığı zaman Cavlâkî dervişler de Moğol ordusuna katılmışlar, fiilen savaşın taraftarı olmuşlardır. Cavlâkî dervişler Kösedağ Savaşı'nda Moğol ordusunun ön saflarında yer almışlardır. Moğollar Kösedağ savaşını takiben Kayseri’yi muhasara ettikleri zaman Cavlâkî dervişler Moğollarla birlikte şehrin surlarından gedik açmaya çalışmış, şehri tahrip etmek için mancınıklarını kullanmışlardır (İbn Bîbî, 1996, s. II/73).

Anadolu'daki ünlü Cavlâkî’lerden birisi Şemsi Tebrîzî'dir. Şems-i Tebrîzî’nin Anadolu'da Moğol aleyhtarlığına karşı mücadele yürütmeye ve halkı Moğollara itaat etmeye çă̆ırdığı Makalat'ında açıkça görülmektedir (Şems-i Tebrîzî, 2006, s. 344, 362). Kayseri'nin Moğollar tarafindan istilasından birkaç ay sonra Şems-i Tebrîzî'nin Konya'ya gitmiştir (23 Ekim 1244). Şems'in müritleriyle birlikte Kayseri'nin Moğol hâkimiyetine girmesinde aktif rol oynaması (Bayram, 2005, s. 142) Konya'daki bazı çevreleri rahatsız etmiştir. Bunların başında Ahiler gelmektedir. Ahilerin suikastı sonucunda öldürüldüğü bilinmektedir.

Burada şunu da ifade etmek gerekir ki; Moğollar istila ettikleri ülkelerde farklı toplulukları veya dini zümreleri birbirleriyle çarpıştırmayı genel bir taktik 
olarak benimsemişlerdi. Böylelikle istilalarını kolaylıkla gerçekleştiriyor veya egemenliklerini tesiste zorlanmıyorlardı. Hatta karşılıklı birbiriyle kavga ettirdikleri taraflardan zayıf olan tarafa destek vererek kuvvetliyi yıpratmak ve gücünü zaafa uğratmak gibi bir siyaset izlerlerdi. Bu açıdan Sünni-Şî̂ çatışmasını desteklemeleri önemlidir. Bu çatışmada Şiileri destekleyerek Sünnilerin gücünü zayıflatmaya çalışmışlardır. Hûlâgû Han ve oğullarının Şiî olan Hace Nâsırü'd-din-i Tusi'yi baş müşavir olarak hizmetlerinde bulundurmaları da siyasetlerinin sonucudur. Moğollar aynı siyaseti Anadolu'da da uyguladılar, farklı dini ve etnik zümreleri birbirine karşı kullandılar. Anadolu'da bazı Türkmenleri ve özellikle de tüm Ahileri kendileri için tehlikeli görüyorlardı. Çünkü Ahilerin Türkmenlere dayanan insan güçlerinin yanında ekonomik güçleri de vardı. Ahilerin "Seyfi" olanları ise savaş̧̧ı ve silahlıydı. Bu bakımdan Türkmenlerin ve Ahilerin gücünü kırmak için Moğolların Kalenderîler (Cavlâkîler) gibi bazı dini gurupları destekleyerek onları Ahilerle vuruşturmaya çalıştıkları görülmektedir. Kendilerine tabi olan veya kendileri tarafindan iş başına getirilen ümeraya destek vererek, onlar vasıtasıyla Türkmenlerin gücünü kırmaya çalıştılar. Bu tutumları Türkmen ve Ahi çevrelerin nefretine yol açmış, zaman zaman Kalenderî gruplara karşı saldırılar gerçekleşmiştir. Şems-i Tebrîzî̀ye yönelik suikast bu açıdan önemlidir.

\section{Yunus Emre}

Yunus Emre'nin hayatı hakkında net bilgiler mevcut değil. Hayatına ilişkin bilinenlerin çoğu efsanevi nitelikli anlatılarda yer alan bilgi kırıntılarından ibaret. Hayatına ilişkin tarihî kayıt ve belgelerin son derece yetersiz oluşu nedeniyle doğum tarihi ve doğduğu yer, Anadolu'da yaşadığı bölge, vefat tarihi ve hatta mezarının yeri konusunda çok farklı görüş ve iddiaların gündeme gelmesine yol açmıştır. Ancak buna rağmen mevcut bazı bilgi kırıntılarına göre bir takım tahminlerde bulunmak da mümkün olabilmiştir. Yunus Emre, araştırmacıların neredeyse tamamına göre 13. yüzyılın ortalarına doğru, bir görüşe göre 1240 tarihinde doğmuş ve 1320 tarihinde vefat etmiştir (Gölpınarlı, 2014, s. XXVIII). Detayda farklı iddia ve görüşler olsa bile Yunus Emre'nin 13. yüzyılın ikinci yarısı ve 14. yüzyılın ilk çeyreğinde yaşadığı kesindir. Hayatının tamamını kapsayan bu dönem ise oldukça önemlidir. Çünkü bu dönem, Yunus Emre'nin hangi siyasi, dini, ekonomik, kültürel ve askeri şartlarda yaşadığına ve bunlardan nasıl etkilendiğine, insanlara yaklaşımının bu şartlardan ne düzeyde ve hangi yönde etkilendiğine ilişkin öngörülerde bulunmayı kolaylaştırmaktadır. Zira söz konusu dönem, yukarıda detaylı olarak açıklandığı üzere Anadolu'da egemen olan bunalım çağına denk gelmektedir.

Önemine binaen söz konusu dönemin özelliklerini satır başlıkları halinde hatırlamak gerekirse; 13. ve 14. yüzyıl, Anadolu tarihinin en karışık, can güvenliğinin en düşük, farklı kesimler arasında çatışmaların en yoğun yaşandığı bir dönemi teşkil etmektedir. Bu dönem Moğolların Anadolu'da terör estirdiği, üretimin durması ve yüksek vergiler nedeniyle insanların aç ve sefil hale düştüğü, Anadolu'nun dağ ve ovalarını başıbozuk toplulukların doldurduğu, çok farklı inanç, anlayış ve yaşayış tarzının birbiriyle husumetli bir şekilde varlık mücadelesi verdiği bir dönemdir. Anadolu bu dönemde askeri, siyasi ve ekonomik nedenlerle Müslüman olma ihtiyacı hisseden fakat esasen İslam'ın ne olduğunu bilmeyen ve İslam dışı önceki inançlarını büyük oranda sürdüren insanların 
köyleri ve şehirleri doldurduğu bir coğrafyadır. Bu çağda Anadolu, 'şeyh', 'mürşit', 'derviş', 'baba' gibi isimlerle kendisine dini, siyasi, askeri misyon tayin etmiş bazı şahsiyetlerin halkı kendilerine çă̆ırdıkları, her çağrının aynı zamanda başkalarına karşı kin ve husumeti de dile getirdiği bir coğrafyadır. En uç dinî yorumlardan, temelsiz itikatlara kadar her inancın, her fikrin kendine yaşam alanı bulduğu bir coğrafyadır. Bazılarının Anadolu'yu istila etmiş putperest ve katil Moğol sürülerine karşı fïli isyan bayrağı açmasına karşılık, diğer bazılarının ise Moğollarla birlikte olmanın, onlarla dostluk kurmanın en doğru yaklaşım olduğunun propagandasını yürüttüğü, istikbali Moğolların yanında görmenin davetini gerçekleştirdiği bir coğrafyadır. Dinin sembol ve ibadetlerini küçümseyen, imanı sulandıran ve din bağını zayıflatan menfi anlayışların toplumsal dokuda ciddi yaralar açtığı, kargaşa ve belirsizliğin kadere dönüştüğü bir coğrafyadır.

Yunus Emre, tüm bu yıkımların, kargaşaların, kin ve husumetlerin var gücüyle devam ettiği bir zamanda yaşamıştır. Birlik ve kardeşliğin, güven ve huzurun, can ve mal emniyetinin olmadığı bir coğrafyanın mensubu olmuştur. Bu çağda ve bu coğrafyada elbette ki tüm bu olumsuz şartlara rağmen huzur ve güveni tekrar tesis etmenin insanların gönüllerine dokunmaktan geçtiğini, bunalımdan çıkışın ancak ilim ve hikmetin ışığını yakmakla mümkün olabileceğini, teker teker herkese hakikatin, iyiliğin, güzelliğin ışığını sunmaktan başka çare olmadığını düşünen ve bu yolda çabalayanlar vardır ve Yunus Emre onlardan birisidir.

\subsection{Fikri Çevresi ve Düşünce Referansları}

Yunus Emre'nin öğrenim düzeyi, ilmi seviyesi konusunda çok farklı bilgiler mevcut olmakla birlikte, belirli bir yaştan sonra mevcut bilgilerini yeterli bulmayıp, hakikat arayışının gereğine uygun olarak farklı bölgelere uzanan seyahatlere çıktığını biliyoruz. Çünkü bunları şiirlerinde kendisi dile getiriyor. Anadolu'yu, Suriye'yi, Azerbaycan ve İran'ı dolaşıp aradığını bulma umuduyla şehir şehir dolaştığını ifade ediyor. Yunus Emre "ilden ile yürüyüp dost sorduğunu; Urum'da, Şam'da kendisi gibi bir garip bulamadığını; âşık olup gurbet ilinde Mecnûn gibi gezdiğini; Kayseri, Tebriz, Sivas, Maraş, Bağdat, Nahçıvan, Şiraz şehirlerini ve bütün Yukarı illeri (Azerbaycan’ı) dolaştıktan sonra Rum'da, yani Anadolu'da bir müddet kışlayıp baharda sılaya döndüğünü” söylüyor (Gölpınarlı,1992, s. 88). Bu konuda şu şiirler dikkat çekicidir: "Ben yürürüm ilden ile dost sorarım dilden dile gurbetde hâlim kim bile gel gör beni aşk neyledi”, "Gezdüm Urum'ıla Şam'ı yukaru illeri kamu çok istedüm bulımadum şöyle garip bencileyin”, "Gurbet ilinde yürürem dostu düşümde görürem uyanıp Mecnûn oluram gel gör beni aşk neyledi”, "Kayseri Tebriz ü Sivas Nahcuvan u Maraş Şiraz Gönül sana Băğdâd yakın âlemlere dîvândasın”, "İndük Rûm'u kışladık çok hayr u şer işledik uş bahâr geldi geri göçdük elhamdülillah”. Bu seyahatleri sirassnda çok farklı kişilerle görüştüğü, çok farklı toplulukların durumuna şahit olduğu kesindir. Ancak şu var ki tüm bu seyahatlerinde aradığını Anadolu'da bulmuştur. Bulduğu ise Hacı Bektaş Velî ve onun bazı halifeleridir.

Yunus Emre'nin fikri açıdan yetişmesine, sıradan insanlar arasından sıyrılıp rehber şahsiyet haline gelişine katkı sağlayan bireysel ve toplumsal şartlar ve faktörler arasında irtibatlı olduğu, bilgi ve tecrübelerinden yararlandığı bazı özel 
şahsiyetlerin önemi oldukça büyüktür. Bunlar içerisinde Hacı Bektaş Velî’nin yeri ise son derece ayrıcalıklıdır. Hayat hikâyesi çok fazla bilinmeyen Yunus Emre'nin hayat hikâyesinden destansı kesitlerin Hacı Bektaş Velî̀nin "Vilayetnâme"sinde kayıtlı bulunması ise son derece manidardır. Bu durum karşılıklı yakınlık içinde olduklarının önemli bir göstergesidir. Yine bu durum, içinde yaşadıkları şartlarda dini, toplumsal, ahlaki, siyasi problemlere ilişkin tespit ve bu problemlerin çözümüne ilişkin aynı değilse bile benzer tutum ve anlayışlara sahip olduklarının önemli bir göstergesidir. Vilayetnâme'deki anlatıdan hareketle ifade etmek gerekirse; bu anlatıda dikkat çeken önemli hususlardan birisi, Yunus Emre'nin arayış içinde olması ve aradığını Hacı Bektaş Velî'de yahut onun halifesi (Tatcı, 1990, s. 29) Taptuk Emre'de bulmasıdır. Özü itibarıyla, Hacı Bektaş Velî, Yunus Emre'nin hakikat arayışında menzil olup, bu menzilde aynı ışıktan nasiplenen başkalarıyla yakınlık içerisinde bulunmuş ve bunu da şiirlerinde ifade etmekten geri durmamıştır. Taptuk Emre'ye ilaveten Barak Baba ve Saltuk Baba bunlardandır. Onlardan nasiplendiğini "Yunus'a Tapduk u Saltuk u Barak'tandır nasip Çün gönülden cûş kıldı ben nice pinhan olam" diyerek açıkça dile getirmiştir. Bu durum Hacı Bektaş Velî çevresinde kalma kararlılığı içerisinde olduğunu göstermesi açısından da önemlidir. Ayrıca şu da dikkat çekici bir husustur ki, Yunus Emre'nin şiirlerinde Geyikli Baba ve Seydi Balum'un isimleri de geçmektedir. Her ikisi de Baba İlyas'in halifelerindendir (Gölpınarlı, 2009, s. 59-61). Dolayısıyla Hacı Bektaş Velî ile ortak bir referansa sahiptir. Zira Hacı Bektaş Velî’nin Baba İlyas ile görüştüğü ve ondan bazı hususlarda etkilendiği bilinmektedir. Ancak onun gibi fiili bir başkaldırı gerçekleştirmemesi, etkilenmesinin daha çok fikri çerçevede kaldığını göstermektedir. Yunus Emre de benzer konumdadır ve bu da muhtemeldir ki Hacı Bektaş Velî̀den etkilenmesinin sonucudur.

$\mathrm{Bu}$ arada şunu da ifade etmek gerekiyor ki, Yunus Emre'nin seyahatleri sırasında uğradığı yerlerden birisi de Konya'dır. Konya'da Mevlana ile görüşmüştür. Bir şiirinde bu görüşmeden bahsetmektedir. Abdülbâki Gölpınarlı'ya göre Yunus Emre, bu görüşme sırasında genç yaştadır ve arayış içerisindedir. Çünkü Mevlana'nın ölüm tarihinde 34 yaşındadır (Gölpınarlı, 2009, s. XXVIII). Yunus, Mevlâna'yı gençlik çağında görmüş̧, onun meclislerinde bulunmuştur: "Mevlânâ meclisinde saz ile işret oldu Arif ma'niye daldı çün biledir ferişte”. Fakat anlatımında özel bir dostluk ifadesinin olmaması ve Meclis'i tanımlayış biçimi bu görüşmeden umduğunu bulamadığına işaret eder gibidir. Hayatının sonraki dönemlerinde aradığını bulmuş birisi olarak Hacı Bektaş Velî ve halifelerinin çevresinde yer alması ise Mevlana ve halifeleriyle irtibatını devam ettirmediğini gösterir niteliktedir. Zira yukarıda açıklandığı üze Mevlana ve Hacı Bektaş arasında fikri yakınlık ve dostluktan bahsetmek pek mümkün değildir.

\subsection{Yunus Emre'de Temel Değerler Dirlik Fikri}

13 ve 14. yüzyıl, Anadolu'da yaşayan toplulukların canının, malının güvenliğinin yanı sira toplumsal aidiyetinde, hayatı ve varlığı anlamlandırmasında kendisine referans olacak bilgi ve yol göstericilere yönelik ihtiyacının en güçlü hissedildiği bir zamanı teşkil etmiştir. Sosyal ve siyasi hayatın karmaşışının yanında dini ve fikrî hayat da bir o kadar hareketli ve karışıktır. Farklı inançlardan ve mezheplerden insanlar birbiriyle inanç ve 
çatışma halindedir. Bu ise birlik ve bütünlüğü engellemekte; işgalcilerin, kişisel iktidar mücadelesi içinde olanların işlerini kolaylaştırmaktadır. Özellikle Moğol saldırıları nedeniyle kesintisiz denebilecek bir sıklık ve yoğunluktaki göç hareketleri mevcut karmaşayı daha da büyütmekte ve artırmaktadır. İşte bu şartlarda Yunus Emre'nin sesi duyulur ve doğruluk, dirlik, sabır, tevazu, cömertlik, sevgi, saygl, tevekkül, kanaatkâr olmak gibi bazı değerlerin sözcülüğün yapar. Buna karşılık olumsuz değerleri de şiirlerinde işler ve bunlar üzerinden insanlara yol göstericilik yapmaya çalışır. Yunus Emre'nin şiirlerinde sıklıkla değindiği ve işlediği olumsuz değerler ise şunlardır: Kibir, öfke, cimrilik, tamahkârlık, kindarlık, kıskançlık, gıybet ve iftira. Yunus Emre için tüm bunların yanı sıra en önemli şey 'dirlik'tir. Bu nedenle şiirlerinde sıklıkla 'dirlik'e atıfta bulunmuştur. Bu tercihinin sebebini anlamak için öncelikle dirlik kelimesinin anlam alanını bilmekte yarar var.

'Dirlik' kelimesinin 13. yüzyıldan öncesinin Türkçesinde 'tirlik' şseklindedir. Kelimenin başındaki 't' 13. yüzyıldan sonra Batı Türkçesinde 'd'ye dönüşmüştür (Çetin, 2019). Sözcüğün kökü olan 'tir' (Hazar, 2012, s. 3); 'yaşam', 'canlılık', 'devinme', 'ayakta durma', 'dikliği sürdürme' gibi anlamlar içermektedir. 'Dirlik', anlam genişlemesiyle 'düzen', 'uyum' gibi kelimelerin karşlığı olarak da kullanılmıştır. 'Sağlık' ve 'huzur' gibi anlamları da içeren kelime 'geçim', 'nafaka', 'geçim tahsisatı', 'varlık' ve 'servet' anlamlarını da kapsamıştır (Tietze, 2002, s. I/ 628). Dirlik kelimesinin türevleriyle birlikte ifade ettiği anlam alanı oldukça geniştir. Köken olarak 'diri' dikkate alındığında bu kökten türeyen sözcükler, dirliğin anlam alanını tespiti kolaylaştırmaktadır. Diri'den türeyen sözcükler şunlardır (Eyuboğlu, 2014, s. 162): 'Dirilik' (canlılık), 'dirilmek' (canlı olmak, yaşama kavuşmak, güçlenmek), 'dirim' (yaşam, hayat), 'diriltmek' (diri kılmak, canlandırmak, güçlendirmek), 'diriliş' (canlanış, yeniden can buluş, güçleniş), 'diretmek' (canlı olduğunu gösterip karşı koymak, dayanmak, gücünü göstermek), 'dirence' (dayanak, destek, karşı koyma olanağı, ayakta durma gücü, mukavemet), 'direniş' (dayanma, karşı koyma), 'diril' (tin, ruh, can), 'dirneşmek' (topluca karşı koymak), 'dirimlik' (sağlık), 'dirişme’ (dayanma), 'dirimseklik' (egemenlik, güçlülük), 'dirgeşmek’ (karşı gelmek, sırtlamak), 'direşmek' (dayanmak, savaşmak, çarpışmak, diretmek), 'direklenmek' (karşı koymak, direk gibi karşısında dikilip durmak), 'direce' (cesaret gösterisi, karşı koyma), 'direcen' (destek, dayanak, payanda. Devrilmek üzere olan duvara, çökmek üzere olan tavana, kökü sağlam olmayan ağaca destek olarak verilen direk), 'direme' (tavanı tutan kalın ağaçtan direk), 'direnbeç' (dayanak, destek/payanda/direk).

Dirlik, kişi açısından dikkate alındığında en yalın anlamıyla 'huzur' ve 'güven' anlamlarına gelmektedir. Bu huzur ve güven hem dünyevî hem de uhrevî bir bağlama sahiptir. Dolayısıyla kişinin dirlik manasındaki huzur ve güveni, kişinin varlık ve hayat anlayışıyla doğrudan ilgilidir. Bu mana üzerinden Yunus Emre'nin dirliğe yüklediği anlam dikkate alındığında Yunus'un dirliği hem dünyevî hem de uhrevî huzur ve güveni ifade edecek şekilde sıklıkla kullandığı tespit edilmektedir. Bu da bir Müslüman olması nedeniyle olması beklenen bir durumdur. Bu durum Yunus Emre'de şöyle dile getirilmiştir: "Degüldür değme yirde ola birlik Sa'âdetdür sana bir eyü dirlik". "İyilik erin yâridir ölse uçmak yeridir Senden sonra söylenir bir dirliğin var ise”. Yunus'a göre bu dirliğin temini ise ancak iyi-kötü, doğru-yanlış, ahlaklı-ahlaksız, hak-batıl ayrımını yapmak ve 
bu ayrımın olumlu tarafında yer alma bilinç ve iradesiyle ilgilidir: "Yola gitme sen egri iy bi-gâne Senün dirligüne sensin bahâne", "Var dîn îmân gerek ise diril bu dünyâda eyü Yarın anda bitmez işün bugün bunda bitmeyince”. Yunus'a göre dünyevî ve uhrevî dirliğe ulaşmak pratiği olmayan bir inançtan yahut boş bir iddiadan ibaret değildir. Dirlik bilincinde olan kişi bunun gereğini yerine getirmelidir. Bunun gereği ise hal ve hareketlerde, yaşantıda dirlik üzerine olmaktır. Yani en genel manasıyla ahlaklı olmaktır.

Yunus Emre için asıl olan ebedî dirliği elde etmektir. Ancak bu da bu kısa dünya hayatından geçmektedir. Bu nedenle dünya hayatının ebedî dirliği elde edecek şekilde yaşanması önem ifade etmektedir: "Eya gönlü açgll gözün fikrin yavlak uzatmagıl Bakgll kendi dirliğine kimse ayıbın gözetmegil Şöyle dirilgil halk ile öleceğiz söyleseler Bâki dirlik budur canım yavuz ad ile gitmegil”.

Yunus Emre ölüm üzerinde de çok durmuştur. Ölümün insan için iyi bir nasihat olduğu inancındadır. Zira dünyevî ve uhrevî dirliğin ancak ölümün nasihat ediciliğini bilmek ve gereklerine uymakla mümkün olabileceğini dile getirmiştir: Nihai amaç sonsuz dirliği elde etmektir. Bunun yolu ise ölüme kadar uzanan bu dünya hayatından geçmektedir. "Neyise dirligün oldur ölümün Bugünki gün durur yarıngı günün”. "Ol vaktin bir olasın ayrulıkdan kalasın Cânsuz gel kapuya bâkî dirlik bulasın”.

Aşk, Yunus Emre için büyük önem ifade eder. Zira aşksız dirliğin dirlik olmayacağı inancındadır. Onun gönlünde dilinde mutlak aşk Allah ile ve Allah içindir. Tüm diğer aşklar onun bir yansımasıdır: "Işk şevkından âlem toldı bu âşılklar andan geldi Işksuz biten çiçek soldı ışkıladur dirlik hoşı", "Dirlik budur âşıka Ma'şûk yolında öle Sorarlarsa eyidem âşıkun burhânını”. Yunus Emre'nin nazarından tüm kâinatta her şeyin sebebi, yaratılışı, doğası aşk üzeredir. Dolayısıyla insanın bütün duyguları aşktır, din ve iman arasındaki her şey aşktır. Tüm oluş ve bozuluş da yine aşk sebebiyle olup onun nazarından özetlenebilecek sonuç; her şeyin aşkın eseri olduğuna dair düşüncesidir (Bayrakdar, 1994, s. 21). Yunus Emre'nin aşk felsefesinin özeti mahiyetindeki "sevelim, sevilelim" mısraı, esasında aşkın kaynağı olan Allah'a doğrudan bir atıftır. Zira sevmek ve sevilmek de mutlak varlık olan Allah'ın vasıflarıdır. Sevginin sebebi ise güzelliktir. Gerçek güzellik ise Cenabı Hakk'a aittir. "Allah, güzeldir ve güzeli sever" şeklindeki hadis-i şerifi tasavvufî açıdan yorumlayan mutasavvıflara göre Allah, kendi güzelliğini temâşâ için kâinatı yaratmıştır. Buna göre âlemin yaratılma sebebi sevgidir. Yani "Ol” emrinde aşk vardır (Özçelik, 2010, s. 93).

Yunus Emre için derviş olmak dirliğe talip olmakla ve dirlik üzere olmakla mümkündür: "Bu dervişlik turagı bir acâyib turakdur Dervîş olan kişiye evvel dirlik gerekdir”. Derviş olan kişinin dirliğe ulaşabilmesi için ayrılıklara değil birliğe, geçici olana değil ebedî olana yönelmesi gerekir: "Oldur erenler dirligi bular bilmez ayyarlıg Anunla bulur erligi kahrı dahı yutmak gerek". "İkiliği terketgil birlik makamın tutgıl Canlar canını bulasın işbu dirlik içinde”. Dervişlik lafla olacak bir şey değildir. Kişinin söyledikleri ile yapıp ettikleri uyuşmalıdır. Görünüşle, lafla derviş olunmaz. Asıl marifet gönlün derviş eylenebilmesidir: "Dervîş olan kişinün dirligi arı gerek Yol içinde hem anun nâmûsı arı gerek".

Yunus Emre'ye göre dine/şegal edip, riata muhalefetle dirliğe ulaşllamaz. Aksini iddia edenler yanılgı içerisindedir. $\mathrm{Bu}$ nedenle dirlik iddiasında 
bulunanların dinin emrettiği ibadetler konusunda hassa olmaları, gereğini yerine getirmeleri gerekmektedir: "Miskîn Yûnus zehr-i kâtil 'ışk elinden tiryâk olur 'İlm ü 'amel zühd ü ta'at pest 'sşksuz helâl olmaya”, "Okımagll 'ilmün yüzin ilme 'amel eyle güzin Aç gönülden bâtın gözin 'âşık-ma'şûk hâline bak”, "Işk îmâmdur bize gönül cemâ’at Kıblemüz dost yüzi dâ’imdür salât Cân dost mihrâbına secdeye vardı Yüz yire uruban ider münâcât Biş vakt tertîbümüz bir vakte geldi Biş bölük oluban kim kıla tâ'at”, "Bir tona bulaşıcak yumayınca mismil olmaz Gönül pâsı yunmayınca namâz edâ olmayısar”, Müsülmânam diyen kişi şartı nedür bilse gerek Tanrı'nun buyrugın tutub biş vakt namâz kılsa gerek".

\section{Sonuç}

13. yüzyılda Moğolların önünde kaçarak Anadolu'ya doluşan topluluklar çok farklı inanç ve karaktere sahiptiler. Onların Anadolu'ya gelip başıbozuk bir halde Anadolu coğrafyasında dolaşmaya başlamaları, çoktandır siyasi, askeri, dini, ekonomik iradesini kaybetmiş Anadolu'yu huzur ve güvenden mahrum hale getirmiştir. Mevcut huzur ve güvenin teminatı olan Anadolu Selçuklu Devleti’nin taht kavgalarına kurban gidişiyle, Moğollar kolay bir şekilde Anadolu'yu işgal edip, Anadolu'da kendi iradelerini egemen kılmışlardır. Moğollar için "dirlik" ve "düzenini" kaybetmiş bir Anadolu, iradelerinin varlık sebebidir. Bu nedenle her türlü karışıklık ve karmaşaya destek olup, Anadolu'yu can ve mal emniyetinin bile olmadığı bir coğrafyaya dönüştürmüşlerdir. Ancak elbette ki bu coğrafyada mevcut bunalımdan kurtuluşun farklı yol ve yöntemine inanan ve bunun gereğine göre hareket eden şahsiyetler çıkmıştır. Ahi Evran bir yandan tacirleri ve zanaatkârları bir araya getirip onlardan bir irade oluşturmaya ve bununla Moğollara fiilen başkaldırarak bunalımdan kurtuluşun kapısını açmaya çalışırken, Hacı Bektaş Velî ise öncelikle gönüllere dokunmanın çabası içesinde olmuş, harap ve paramparça olmuş gönülleri tekrar birleştirmenin çabasını yürütmüştür. Zira inanç ve ahlakta dirliğini kaybetmiş halkın ancak teker teker yeniden inşa edilmesiyle hakikatin ışığının yakılabileceğini, dirliğin tesis edilebileceğini düşünmektedir. Yunus Emre'de benzer anlayışla hareket etmiş, öncelikle gönüllere dokunmak, hakikati almaya ve anlamaya uygun gönüller inşa etmek gerektiğini düşünenlerdendir. Ancak böylelikle kaybedilmiş olan dirlik tekrar inşa edilebilecektir. Bu nedenle şiirlerinde ele alıp işlediği değerler arasında "dirlik" çok ayrıcalıklı bir yerde durmaktadır. Tüm anlatımlarını, görüşlerini, iddialarını hep "dirlik”i referans alarak dile getirmiştir.

\section{Kaynakça}

Ahmet T. Karamustafa, A. T. (2017). Yesevîlik, Melametîlik, Kalenderîlik, Vefâîlik ve Anadolu tasavvufunun kökenleri sorunu. Hoca Ahmed Yesevi Seçme Makaleler. Ankara: Ahmet Yesevi Üniversitesi, 25-150.

Akkuş, M. (2011). Ilhanlıların Anadolu'daki dinî siyaseti. (Yayınlanmamış Doktora Tezi). Konya: Selçuk Üniversitesi Sosyal Bilimler Enstitüsü.

Akkuş, M. (2013). Ateş ve ocak kültünün Anadolu'da yayginlaşmasında Moğolların etkisi. Türk Kültürü ve Hacı Bektaş Veli Araştırma Dergisi, (68), 15-32.

Akkuş, M. (2013). Hacı Bektaş Velî’nin Moğol tahakkümüne bakışı. Türk Kültürü ve Hacı Bektaş Velî Araştırma Dergisi, 66, 147-168. 
Akkuş, M. (2014). Anadolu Selçuklu Devletinin yıkılmasında Kalenderi grupların rolü. Turkish Studies, 9(7), 117-134.

Aksarâyî. (2000). Musameratü’l Ahbar. (M. Öztürk, Çev.). Ankara: Türk Tarih Kurumu Yayınları.

Algar, H. (2000). Kübreviyye, Diyanet Işsleri Başkanlı̆̆ı İslam Ansiklopedisi, XXXII, 500-501.

Aşıkpaşazade. (1970). Aşıkpaşaoğlu tarihi. İstanbul: Milli Eğitim Bakanlığı Yayınları.

Bağcı, B. (2020). Osmanlı Devleti’nin kuruluş döneminde Kalenderî gruplar. Ortaçă̆ Araştırmaları Dergisi, 3(2), 240-252.

Bayrakdar, M. (1994). Yunus Emre ve aşk felsefesi. İstanbul: Türkiye İs Bankası Kültür Yayınları.

Bayram, M. (1978). Ahi Evren kimdir? Gerçek şahsiyeti ve eserleri. Türk Kültürü, XVI. 658-668.

Bayram, M. (1995). Ahi Evren, tasavvufî düşüncenin esasları. Ankara: Türkiye Diyanet Vakfi Yayınları.

Bayram, M. (2002). "Bacıyân-I Rum (Anadolu Bacıları) ve Fatma Bacı. Türkler. H. Celal Güzel vd. (Ed). Ankara: Yeni Türkiye Yayınları.

Bayram, M. (2003). Türkiye Selçukluları döneminde bilimsel ortam ve Ahiliğin doğuşuna etkisi. Türkiye Selçukluları Üzerine Araştırmalar, Konya: Kömen Yayınları.

Bayram, M. (2005). Sosyal ve siyasi boyutlarıyla Ahi Evren-Mevlânâ mücadelesi. Konya: Nüve Kültür Merkezi.

Cahen, C. (2000). Osmanlllardan önce Anadolu. İstanbul: Tarih Vakfı Yurt Yayınları.

Coşan, E. (2019). Hacı Bektaş-ı Veli Makalât, İstanbul: Server Yayınları.

Çetin, F. N. (2019). Yunus Emre’de “dirlik” düşüncesi. (Yayımlanmamış Yüksek Lisans Tezi). Konya: Necmettin Erbakan Üniversitesi.

Dinç, A. (2014). Türkçenin kayıp kelimeleri, İstanbul: Litera Yayıncılık.

Eflâkî, A. (1989). Menakibüll arifin. (T. Yazıcı, Çev.). İstanbul: Milli Eğgitim Bakanlığı Yayınları.

Elvan Çelebi. (1995). Menakıbu’l-kutsiyye fi menasıbu'l-ünsiyye. (İ. E. Erünsal, A. Y. Ocak, Hazırlayan). Ankara: Türk Tarih Kurumu Yayınları.

Erdem, İ. (2003). Türkiye Selçuklu-ilhanlı iktisadi, ticari ilişkileri ve sonuçları. Ankara Üniversitesi Dil ve Tarih-Coğrafya Fakültesi Tarih Bölümü Tarih Araştırmaları Dergisi, 21 (33), 49-67.

Ergin, O. N. (1958). Sadrü'd-din al Konevî ve eserleri. Şarkiyat Mecmuası, II, 63-90.

Eröz, M. (1992). Eski Türk dini (Gök Tanrı inancı) ve Alevilik Bektaşilik, İstanbul: TDAV Yayınları. 
Eyuboğlu, İ. Z. (2014). Türk dilinin etimoloji sözlüğü. İstanbul: Sosyal Yayınları.

Eyupoğlu, İ. Z. (1998). Bütün yönleriyle Hacı Bektaş-ı Velî. İstanbul: Özgür Yayınları.

Eyyüp, Y. (2016). Tasavvuf'un Anadolu'ya yayılmasında Moğol İstilasının Etkisi, (Yayımlanmamış Yüksek Lisans Tezi), Sakarya Üniversitesi, Adapazarı.

Faik Aslan, Hacı Bektaş-I Velînin düşünce dünyası, (Yayımlanmamış Yüksek Lisans Tezi), Sivas: Cumhuriyet Üniversitesi.

Firdevsi Rumi, (2007). Velâyet-nâme, (Hamiye Duran, Hazırlayan). Ankara: Türkiye Diyanet Vakfı Yayınları.

Gökbulut, S. (2009). Necmeddîn Kübrâ ve Kübrevîlik. (Yayımlanmamış Doktora Tezi), İzmir: Dokuz Eylül Üniversitesi.

Gölpınarlı, A (1992). Alevi-Bektaşi nefesleri. İstanbul: İnkılap Kitabevi.

Gölpınarlı, A. (2009). Yunus Emre Hayatı ve bütün şiirleri. İstanbul: Türkiye $\dot{I}_{\widehat{s}}$ Bankası Kültür Yayınları.

Gölpınarlı, A. B. (1931). Melâmîlik ve Melâmîler. İstanbul: Devlet Matbaası.

Gülten, S. (2012). Tahrir defterlerine göre Anadolu'da Kalenderîler ve Haydarîler. Tarih Araştırmaları Dergisi, 31(52), 35-53.

Hacıgökmen, M. A. (2001). Anadolu Selçukları zamanında, Sadreddin Konevî̀nin Türkmen isyanlarına bakışı. Türkiyat Araştırmaları Dergisi, 10, 39-49.

Hazar, M. (2012). Türkiye Türkçesinde işlek olmayan sözcük kökleri. Uluslararası Yaşayan Türkçe Bilgi Şöleni-Prof. Dr. Faruk Kadri Timurtaş Hatırasina. İstanbul.

İbn Bibi. (1996). El evamirül alaiye fil umuril-Alaiye (Selçukname). (M. Öztürk, Çev.). Ankara: 1000 Temel Eser Kültür Bakanlığı.

İbn-i Batuta, Tam metin seyahatname. (Mümin Çevik, Çev.). İstanbul: Üçdal Neşriyat.

Karamustafa, A. T. (2011). Tanrı'nın kuraltanımaz kulları; İslâm dünyasında derviş toplulukları (1200-1550), (Ruşen Çakır, Çev.), İstanbul: Yapı Kredi Yayınları.

Kartal, K. (2006). Anadolu Selçukluları ve Beylikler döneminde şiir ve şairler. Anadolu Selçukluları ve Beylikler Dönemi Uygarlĭ̆ı I (Sosyal ve Siyasal Hayat), A. Y. Ocak (Ed.), Ankara.

Köksal, M. F. (2012). Ahi Evran'ın menkabevi hayatına dair bilinmeyen bir eser: Menâkıb-ı Ahî Cihân-ı Nasreddîn Ahi Evran, Türk Kültürü ve Hacı Bektaş Velî Araştırma Dergisi, 62, 83-108.

Köprülü, F. (1996). Anadolu'da İslâmiyet. İstanbul: İnsan Yayınları.

Köprülü, F. (19981). Osmanlı imparatorluğunun kuruluşu. İstanbul: Ötüken Yayınları.

Kutluay, E. (2010). Alevi Bektaşî gerçeği. İstanbul: Alfa Yayınları. 
Melikoff, I. (2010). Hacı Bektaş efsaneden gerçeğe. (T. Alptekin, Çev.). İstanbul: Cumhuriyet Kitapları.

Molla Camî, (1981). Nefahat'ül-üns min hazarat'il-Kudüs; mukaddes makamlardan huzur nefesleri. (A. Akçiçek, Çev.), İstanbul: Sağlam Kitabevi.

Muhammed Sivasî. (2008). Şeyh Evhadüddin Hamit el-Kirmani ve menakıb namesi. (M. Bayram, Çev.). Konya: NKM Yayınları.

Ocak, A. Y. (1996). Hacı Bektaş-ı Velî. Türkiye Diyanet Vakfı İslam Ansiklopedisi, XIV, 455-458.

Ocak, A. Y. (1999). Osmanlı imparatorluğunda marjinal sufilik Kalenderîler (XIV-XVII. yüzyıllar). Ankara: TTK Yayınları.

Ocak, A. Y. (2006). Selçuklular ve beylikler devrinde tasavvufî düşünce. Anadolu Selçukluları ve Beylikler Dönemi Uygarlığı I (Sosyal ve Siyasal Hayat). A. Y. Ocak (Ed), Ankara.

Ocak, A. Y. (2012). Türk sufîliğin bakışlar. İstanbul: İletişim Yayınları.

Ocak, A. Y. (2018). Türk sufiliğine bakışlar. İstanbul: İletişim Yayınları.

Özçelik, M. (2010). Bizim Yunus. Eskişehir: Eskişehir Valiliği Yayınları.

Şems-i Tebrîzî. (2006). Makalat. (O. N. Gençosman, Çev.). İstanbul: Ataç Yayınları.

Tatcı, M. (1990). Yunus Emre divanı inceleme, Ankara: Kültür Bakanlığı Yayınları.

Tietze, A. (2002). Tarihi ve etimolojik Türkiye Türkçesi lügati. İstanbul: Simurg Kitapçılık.

Togan, Z. V. (1981). Umumi Türk tarihine giriş, İstanbul: Enderun Yayınları.

Turan, A., Yıldız, H. (2008). Tarihten günümüze Anadolu Aleviliği. Ondokuz Mayıs Üniversitesi Illahiyat Fakültesi Dergisi, 26(26-27), 11-24.

Turan, O. (1973). Doğu Anadolu Türk devletleri tarihi, İstanbul: İstanbul Matbaası.

Turan, O. (1998). Selçuklular tarihi ve Türk İslam medeniyeti. İstanbul: Boğaziçi Yayınları.

Turan, O. (2010). Selçuk Türkiye'si din tarihine dair bir kaynak Fustadül'l Adale Fi Kavaidi's Saltanata. Köprülü Armăganı. Ankara: Türk Tarih Kurumu Yayınları. 531-564.

Turan, O. (2012). Selçuklular ve İslâmiyet. İstanbul: Ötüken Neşriyat.

Ülken, H. Z. (2003). Anadolu'nun dinî sosyal tarihi (öncüler Barak Baba, Geyikli Baba, Hacı Bektaş). (A. Taşğın, Çev.), Ankara: Kalan Yayınları.

Ünver, İ. (2006). Yûnus Emre üzerine, TÜBAR-XIX, Bahar Sayısı, 489-498.

Yaylımov, G. (2012). Necmeddîn-i Kübrâ ve Anadolu'da Kübrevîlik, (Yayımlanmamış Yüksek Lisans Tezi), Bursa, Uludağ Üniversitesi. 
Yazıcı, T. (1968). Kalenderlere dair yeni bir eser. Necati Lugal Armağanı, Ankara, $786-787$.

Yıldız, H. (2012). Hacı Bektaş Velî ile Ahi Evran ilişkisi. Türk Kültürü ve Hacı Bektaş Velî Araştırma Dergisi, 61, 187-206. 